\title{
Vegetação, unidades fitoecológicas e diversidade paisagística do estado do Ceará
}

Vegetation, phytoecological regions and landscape diversity in Ceará state, northeastern Brazil

\author{
Marcelo Freire Moro ${ }^{1,7}$, Mariana Bezerra Macedo ${ }^{2,3}$, Marcelo Martins de Moura-Fé, $e^{4,5}$, Antônio Sérgio \\ Farias Castro ${ }^{5}$, Rafael Carvalho da Costa ${ }^{6}$
}

\begin{abstract}
Resumo
Esse artigo apresenta uma revisão dos tipos vegetacionais do estado do Ceará a partir de sua diversidade paisagística, centrando-se, notadamente, nas condições climáticas e unidades geomorfológicas. Com base em levantamentos de campo, literatura especializada e mapas das unidades fitoecológicas e geomorfológicas, pretendemos expor, de forma didática, a caracterização, distribuição e principais ameaças antrópicas concernentes a cada vegetação. Por fim, utilizamos métodos de análise multivariada para comparar a similaridade de espécies entre os diferentes levantamentos florísticos disponíveis para o estado e discutimos os padrões biogeográficos observados.
\end{abstract}

Palavras-chave: Biogeografia, relevo, geomorfologia, vegetação, Nordeste do Brasil, semiárido.

\begin{abstract}
This article presents a review of the vegetation types occurring in Ceará state, Northeastern Brazil. We explain how climate and geomorphology have produced the different landscapes in Ceará and aim to characterize the main features, distribution and anthropogenic threats for each vegetation type. To achieve this we performed fieldwork and evaluated available maps and the literature in order to summarize the main attributes of each vegetation type. We also compiled floristic surveys for Ceará state and used multivariate analysis to compare the similarity of species composition among the different phytoecological units and to interpret the biogeographical patters observed.
\end{abstract}

Key words: Biogeography, relief, geomorphology, vegetation, Northeastern Region of Brazil, semiarid.

\section{Introdução}

Inspecionando o "Mapa de Biomas do Brasil: primeira aproximação” (IBGE 2004; Fig. 1), somos levados a pensar, num primeiro momento, que o estado do Ceará é totalmente coberto pela vegetação de caatinga. Isso de modo algum é verdadeiro. A proposição fitogeográfica apresentada no mapa do IBGE (2004) divide o Brasil em seis biomas, representando de modo simplificado os grandes domínios fitogeográficos brasileiros. Se por um lado essa divisão simplificada facilita o planejamento de políticas públicas para o manejo e conservação da biodiversidade em nível nacional, por outro obscurece o fato de que cada domínio fitogeográfico abrange um espaço geográfico heterogêneo, onde ocorrem diferentes tipos de vegetação. Isso potencializa problemas na tomada de decisões nas escalas estaduais e municipais e na execução de ações de conservação e manejo na escala local.

\footnotetext{
Instituto de Biologia Universidade Estadual de Campinas (UNICAMP), Depto. Biologia Vegetal, B1 M. CP 6109, 13083-970, Campinas, SP, Brasil.

${ }^{2}$ Instituto Federal de Educação, Ciência e Tecnologia do Piauí, 64600-000, Picos, PI, Brasil.

${ }^{3}$ Universidade de São Paulo (USP), Depto. Geografia, Av. Professor Lineu Prestes 338, Cidade Universitária, 05508-900, São Paulo, SP, Brasil.

${ }^{4}$ Universidade Federal do Ceará (UFC), Depto. Geografia, Campus do Pici, Centro de Ciências, 60455-760, Fortaleza, CE, Brasil.

${ }^{5}$ Universidade Regional do Cariri (URCA), Depto. Geociências (DEGEO), 63105-000, Crato, CE, Brasil.

${ }^{6}$ Universidade Federal do Ceará, Depto. Biologia, Campus do Pici, Centro de Ciências, B1. 906, 60455-760, Fortaleza, CE, Brasil.

${ }^{7}$ Autor para correspondência: bio_moro@yahoo.com.br
} 
Pretendemos neste trabalho fornecer subsídios que contribuam para uma compreensão geral do quadro vegetacional do estado do Ceará. Para isso utilizamos uma escala mais apropriada para o estado do que a escala nacional e abordamos cada unidade fitoecológica de maneira integrada, a partir de sua interação com os demais elementos paisagísticos, dentre os quais destacamos o clima, a geologia e o relevo.

O Ceará já é alvo de estudos botânicos há cerca de 200 anos (Paiva 2002). Um dos estudos pioneiros foi o trabalho realizado pelo naturalista João da Silva Feijó (1760-1824). Feijó chegou à capitania do Ceará em 1799 e produziu um manuscrito intitulado "Collecção Descriptiva das Plantas da Capitania do Seará” (Feijó 1818; Pereira \& Santos 2012), mas parte desse manuscrito se perdeu e, sem ter sido publicado, teve influência limitada sobre os estudos botânicos posteriores (Paiva 2002).

Uma expedição mais influente foi a famosa “Comissão Científica de Exploração”, liderada pelo botânico Francisco Freire Alemão (17971874). Instituída pelo imperador Dom Pedro II, a expedição percorreu o território cearense entre 1859 e 1861 e deixou um conjunto de publicações e manuscritos que enriqueceram a compreensão fitogeográfica do estado (Paiva 2002; Braga 1962). Francisco Freire Alemão e outros naturalistas já percebiam, em suas incursões pelo Ceará, a heterogeneidade paisagística e vegetacional da província, chamando atenção para as claras diferenças entre a flora da região costeira, do interior semiárido e das serras úmidas (Huber 1908; Loefgren 1923). O trabalho de Alemão forneceu os primeiros esboços da organização

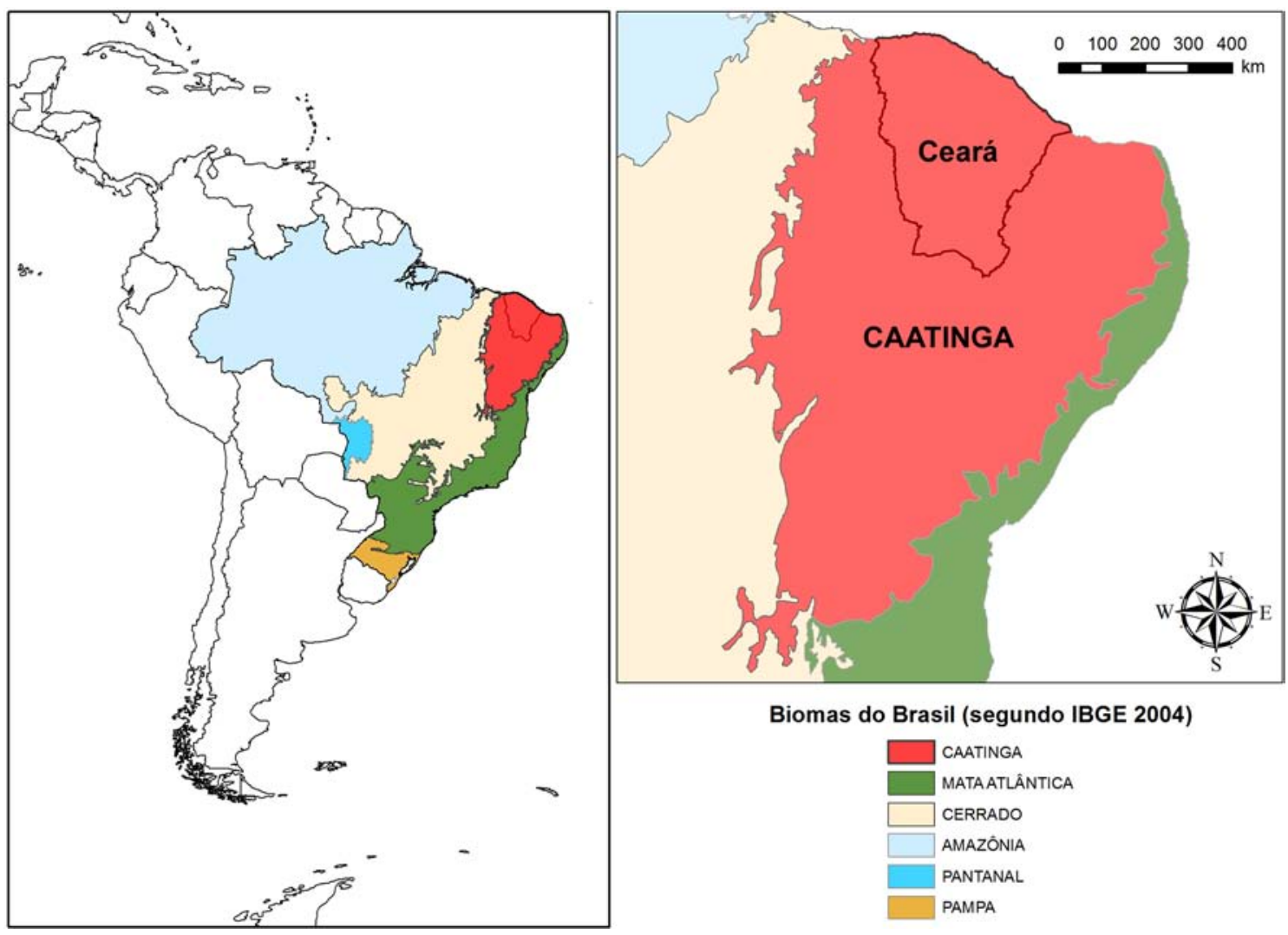

Figura 1 - Localização geográfica dos domínios fitogeográficos do Brasil (biomas sensu IBGE 2004) e do estado do Ceará. Devido à escala do mapa do IBGE (2004), o Ceará aparece completamente circunscrito à Caatinga. Entretanto, o estado apresenta um conjunto diversificado de paisagens e vegetações. Elaboração do mapa: M.F. Moro, baseado em IBGE 2004. Figure 1 - Geographical location of the Brazilian phytogeographical domains and the position of Ceará state, mapped within the Caatinga Domain. Due the broad scale used by IBGE (2004), Ceará is shown as containing only caatinga within its borders. But the actual situation is that the state has a diversified set of vegetation and landscapes. 
fitogeográfica do território do Ceará, o que acabou por influenciar os sistemas atuais de classificação fitogeográfica do estado. As categorias de ambientes reconhecidos por ele são relativamente equivalentes (mesmo com a mudança de nomes) ao que usamos hoje em dia.

Também destacamos o trabalho do naturalista sueco Alberto Loefgren (1854-1918), que em seu trabalho "Notas Botânicas (Ceará)" (Loefgren 1923) percebeu as diferenças florísticas entre a região costeira, a caatinga do interior e as serras úmidas, chamando-as de "agrupamentos florísticos". Loefgren atentou para processos ecológicos da caatinga, como a caducifolia e a presença de muitas ervas anuais (terófitas), componentes fundamentais da biota do semiárido. Entre o século XIX e início do século XX, os naturalistas basicamente fizeram levantamentos e elaboraram listagens da flora, com descrições gerais sobre as diferentes fitofisionomias presentes no Ceará. O trabalho desses naturalistas forneceu a base para os sistemas fitogeográficos propostos para o estado no século XX.

Na década de 1980 a fitogeógrafa Maria Angélica Figueiredo (1939-2012), professora e pesquisadora da Universidade Federal do Ceará, percorreu amplamente o estado e elaborou um mapa, denominado de "Unidades Fitoecológicas", contendo as respectivas descrições das fisionomias e principais elementos de cada tipo de vegetação do estado, que foi publicado no "Atlas do Ceará" (IPLANCE 1997; SUDEC 1986). Para denominar as unidades fitoecológicas, Figueiredo (1986, 1997) baseou-se na classificação proposta no mapa de vegetação do Atlas Nacional do Brasil, de 1966. Porém, após a publicação pelo IBGE do "Manual de vegetação adaptada a um sistema universal" (IBGE 2012; Veloso et al. 1991), a nomenclatura utilizada no mapa de Unidades Fitoecológicas do estado do Ceará ficou desatualizada. Entretanto, a proposta cartográfica de Figueiredo (1997) para a fitogeografia do Ceará, com pequenas modificações feitas posteriormente pelo Instituto de Pesquisa e Estratégia Econômica do Ceará (IPECE), é atualmente a melhor disponível para a escala do Ceará.

Assim, objetivamos atualizar o sistema fitogeográfico de Figueiredo a partir de dados recentes e traçar uma síntese que permita, por meio de explicações e mapas didáticos, a compreensão do quadro vegetacional do estado, a partir da interação da vegetação com os demais elementos físicos que caracterizam a diversidade paisagística do território cearense, especialmente a geomorfologia. Esse artigo foi escrito em uma parceria entre diferentes pesquisadores da biologia e da geografia. Ele visa ser um texto introdutório e didático sobre a fitogeografia do território cearense, de modo a oferecer suporte às monografias da Flora do Ceará que estão sendo publicadas (Matias \& Sousa 2011; Sousa \& Matias 2013; Menezes et al. 2013; Soares Neto et al. 2014) e a estudos gerais sobre a biota (fauna, flora ou fungos) do estado.

\section{Métodos}

Apresentamos aqui uma descrição sintética dos elementos climáticos, geológicos e geomorfológicos com ênfase numa caracterização fitogeográfica para o estado do Ceará. Nos baseamos em observações de campo e trabalhos acadêmicos para atualizar a proposta de classificação da vegetação do estado feita no Atlas Geográfico do Ceará (Figueiredo 1997; IPLANCE 1997). Assim, esse trabalho se fundamentou em uma breve revisão histórica das publicações fitogeográficas do Ceará somado a uma explicação sobre cada vegetação do estado, baseado na experiência de campo dos autores e na literatura florístico-fitossociológica publicada.

O mapa de vegetação apresentado foi modificado a partir do sistema fitogeográfico do Ceará de Figueiredo (1997), obtidos junto à Fundação Instituto de Pesquisa e Informação do Ceará (IPLANCE). Já o mapa geomorfológico apresentado aqui foi elaborado a partir do Mapa Geológico do Estado do Ceará (CPRM [Serviço Geológico do Brasil] 2003) e das Cartas Topográficas da SUDENE (1999), além de diferentes mapas geomorfológicos e hipsométricos, e diversos levantamentos de campo. Também produzimos um acervo fotográfico sobre as vegetações do estado (<http://dx.doi.org/10.6084/ m9.figshare.1289920>), a fim de documentar parte da diversidade paisagística do Ceará. Os tipos de solos citados neste artigo seguem o sistema estabelecido pela EMBRAPA (2006).

Para cada habitat e vegetação discutidos neste trabalho indicamos algumas espécies características. A lista completa das espécies características, acompanhadas de seus respectivos autores e famílias, está disponível como suplemento digital a este artigo ( $<$ http://dx.doi. org/10.6084/m9.figshare.1289930>). 
Ao produzir a discussão aqui proposta, buscamos demonstrar os elos existentes entre o ambiente físico e a vegetação do Ceará. A vegetação não surge ao acaso, mas é fruto da ação do clima, dos tipos de solo, do relevo e dos processos histórico-biogeográficos atuando conjuntamente. Assim, abordaremos as vegetações a partir da sua relação com o ambiente, pois esta opção torna a análise mais rica, ao evitar a recorrente separação observada entre estes temas em diversos textos acadêmicos. Partimos da descrição dos diversos ambientes físicos que compõem o território cearense para, em seguida, relacionar estes ambientes às fitofisionomias que lhe são correspondentes, fornecendo, dessa maneira, um quadro teórico que facilite um reconhecimento geral das unidades fitoecológicas do Ceará.

Embora o sistema de Figueiredo (1997) seja bastante didático, há alguns pontos problemáticos do ponto de vista cartográfico. O mais pungente é a subdivisão da vegetação de caatinga da Depressão Sertaneja (áreas cristalinas) em várias subunidades (caatinga arbórea, caatinga arbustiva aberta, caatinga arbustiva densa e mata seca). Até que ponto é útil cartograficamente dividir a caatinga de áreas cristalinas em unidades fitoecológicas diferentes é algo a ser analisado com cuidado. De fato encontramos no Ceará diferentes portes fisionômicos nas caatingas do cristalino, variando de porte arbóreo ao arbustivo e de densidade aberta até fechada, mas todas essas áreas possuem uma flora típica das superfícies cristalinas que as une entre si.

Nossa experiência de campo indica que o que Figueiredo (1997) classifica como caatinga arbórea, caatinga arbustiva aberta, e caatinga arbustiva densa são variações no porte e no estado de conservação de uma unidade fitoecológica única, possuidora de flora coesa que optamos por chamar de caatinga do cristalino. Durante trabalhos de campo, por vezes observamos que áreas indicadas no mapa de Figueiredo (1997) como caatinga arbustiva têm porte arbóreo e vice versa, tornando difícil atribuir uma delimitação cartográfica separada para cada variação fisionômica da caatinga do cristalino. Também é difícil determinar quando essas diferenças são devidas a fatores naturais (diferenças na profundidade dos solos ou na precipitação), ou ao histórico de impactos antrópicos de uma dada área.

Em uma comparação fitogeográfica dos tipos de caatinga do semiárido brasileiro, Moro
(2013) mostrou que as formações vegetais que ocupam superfícies sedimentares distantes entre si (bacias sedimentares da Ibiapaba-Araripe, Tucano-Jatobá e Dunas do São Francisco) são mais semelhantes floristicamente entre si do que com a flora de áreas adjacentes sobre superfícies cristalinas. Do mesmo modo, caatingas ocupando áreas cristalinas são mais parecidas entre si do que com as caatingas de áreas sedimentares próximas. Com isso, consideramos que a caatinga do cristalino é uma única unidade fitoecológica, ao invés de três unidades distintas (caatinga arbórea, caatinga arbustiva densa e caatinga arbustiva aberta). Essas variações fisionômicas, no entanto, são observáveis em campo, como mostramos na Prancha 3 do Apêndice 1. Assim, de um ponto de vista prático, pesquisadores em campo poderão indicar, se desejarem, em qual das variações fisionômicas da caatinga do cristalino estão trabalhando, embora consideremos aqui que todas essas áreas devam ser tratadas como uma única unidade fitoecológica para fins de classificação geral. As matas secas são áreas de porte florestal localizada tanto nas serras de origem cristalina quanto sedimentar. Entretanto, é possível que sua flora seja mais próxima da flora da caatinga do cristalino e da caatinga do sedimentar, a depender se a mata seca está em uma superfície de origem cristalina ou sedimentar, do que entre matas secas sobre diferentes geologias. Até que ponto as matas secas formam um grupo florístico particularizado no contexto fitogeográfico do Ceará é um assunto a ser esclarecido por estudos futuros.

\section{Análises florísticas}

Para avaliar a relação entre a geomorfologia e as floras dos diferentes tipos de vegetação do estado, realizamos uma análise biogeográfica utilizando análises multivariadas (Legendre \& Legendre 2012; McCune \& Grace 2002). Selecionamos levantamentos florísticos realizados no Ceará e criamos uma matriz de presençaausência, registrando quais espécies ocorriam em cada área (Apêndice 2; Suplemento Digital 2). A similaridade entre os diferentes ambientes foi comparada por distância de Bray-Curtis (Sørensen) utilizando uma análise de agrupamento (com algoritmo UPGMA) e de ordenação (utilizando Ordenação Multidimensional não Métrica - NMS - com duas dimensões finais) (Legendre \& Legendre 2012; McCune \& Grace 2002). Para a análise, espécies sem identificação 
completa (i.e. espécies reportadas como “sp.”) foram excluídas e espécies com identificação dúbia (i.e. reportadas como "cf." e "aff.”) foram consideradas como corretamente identificadas. Nas comparações, demos preferência a levantamentos publicados, mas alguns levantamentos florísticos não publicados, disponíveis na forma de trabalhos de conclusão de curso ou teses de pós-graduação, foram incluídos como complementação das análises (Apêndice 2). Nas comparações de flora, utilizamos todas as espécies de plantas vasculares reportadas nos levantamentos, incluindo plantas lenhosas e herbáceas.

\section{Nomenclatura}

A nomenclatura associada à vegetação varia não só segundo a nomenclatura regional, mas também de acordo com as diversas propostas formais. Assim, os nomes utilizados por este trabalho, pelo Atlas do Ceará (Figueiredo 1997) e pelo IBGE (Veloso et al. 1991; IBGE 2012) diferem. Para sanar esse problema, o Apêndice 3 traz uma tabela comparando a nomenclatura utilizada nos três contextos. Um organograma didático é apresentado no Apêndice 4, mostrando a relação entre as unidades de relevo do Ceará e os tipos de vegetação que as ocupam.

\section{Resultados e Discussão}

\section{Caracterização Ambiental do Ceará}

O território do Ceará ocupa uma superfície de 148.825,60 km², é o $4^{\circ}$ maior estado da região Nordeste do Brasil, sendo limitado ao norte pelo Oceano Atlântico, ao sul pelo estado de Pernambuco, ao leste pelo Rio Grande do Norte e pela Paraíba, e a oeste pelo Piauí (IPLANCE 1997).

A maior parte do território cearense encontrase inserida no contexto semiárido nordestino em virtude das condições climáticas dominantes, aspecto que corrobora para sua classificação como um dos estados mais secos do país (Zanella 2005). Contudo, em função de fatores geográficos locais, tais como a altitude e a proximidade do oceano, apresenta áreas úmidas e sub-úmidas que condicionam contrastes significativos no quadro natural cearense (Silva \& Cavalcante 2004). Em decorrência dessas variações, embora o estado esteja majoritariamente sob a influência de um macroclima semiárido, os gradientes de chuva, temperatura e umidade se alteram consideravelmente do litoral para o interior, condicionando um gradiente de umidade e influindo na diversidade de ambientes que caracterizam o mosaico paisagístico cearense. A região costeira e as serras, por exemplo, recebem uma quantidade bem maior de chuvas que a depressão sertaneja (IBGE 2002; Nimer 1972), configurando encraves paisagísticos diferenciados daqueles encontrados no sertão seco do interior do estado.

As características climáticas atualmente vigentes no Ceará notabilizam-se pelo predomínio de temperaturas médias do ar elevadas durante a maior parte do ano e uma pequena amplitude anual na temperatura média, já que o estado é tipicamente quente o ano todo. Já as chuvas variam bastante ao longo do ano, com níveis de precipitação concentrados no $1^{\circ}$ semestre, os quais, por sua vez, condicionam a vazão da hidrografia regional (Zanella 2005).

De acordo com Nimer (1977), a região Nordeste é submetida à forte radiação solar devido ao ângulo de inclinação solar, comum a todas as regiões intertropicais do planeta. Em virtude disso, a quantidade de calorias absorvidas pelos níveis inferiores da atmosfera na região é intensa e com isso, as médias das temperaturas anuais são elevadas, derivando em médias térmicas anuais situadas entre $26^{\circ}$ e $28^{\circ} \mathrm{C}$ (Nimer 1972, 1977, 1989).

Se em relação à temperatura o Nordeste apresenta certa homogeneidade espacial, o mesmo não acontece em relação à pluviosidade. De maneira geral, os índices pluviométricos se distribuem de modo decrescente do litoral para o interior, consequência da menor influência dos ventos alísios sobre as regiões mais interiores (Nimer 1972, 1989), onde as serras elevadas constituem verdadeiras ilhas de exceção no contexto semiárido.

O quadro delineado para o Nordeste aplicase ao estado do Ceará, ou seja, há o predomínio de temperaturas médias do ar elevadas durante a maior parte do ano, resultando em uma pequena amplitude térmica anual, em contraponto com níveis de precipitação que podem ser compartimentados em duas estações bem distintas: uma estação chuvosa, que se inicia em dezembro e declina em maio, com a ocorrência de precipitações bastante erráticas, e o restante do ano, com o predomínio de uma estação seca, marcada pela estiagem pluviométrica.

As características climáticas apresentadas acima, representadas pela sazonalidade das 
precipitações, mantêm uma relação direta com o comportamento fluvial (Zanella 2005). A distribuição espaço-temporal das chuvas, associada às características topográficas, geomorfológicas e geológicas, condicionam uma rede hidrográfica sazonal no estado, onde os rios tipicamente secam após a época das chuvas.

Esse quadro hidroclimático é o principal responsável pela modelagem das unidades geomorfológicas do estado, as quais são apresentadas no Mapa Geomorfológico Simplificado do Ceará (Fig. 2) e descritas no decorrer deste texto de acordo com CPRM [Serviço Geológico do Brasil] (2003), EMBRAPA (2006), Pereira \& Silva (2005) e Zanella (2005), além de análises geomorfológicas.

A formação dos terrenos que hoje compõem o território do Ceará é antiga e se deu com maior propriedade no Cretáceo (por volta de 100 milhões de anos antes do presente), em virtude de processos de reativação tectônica

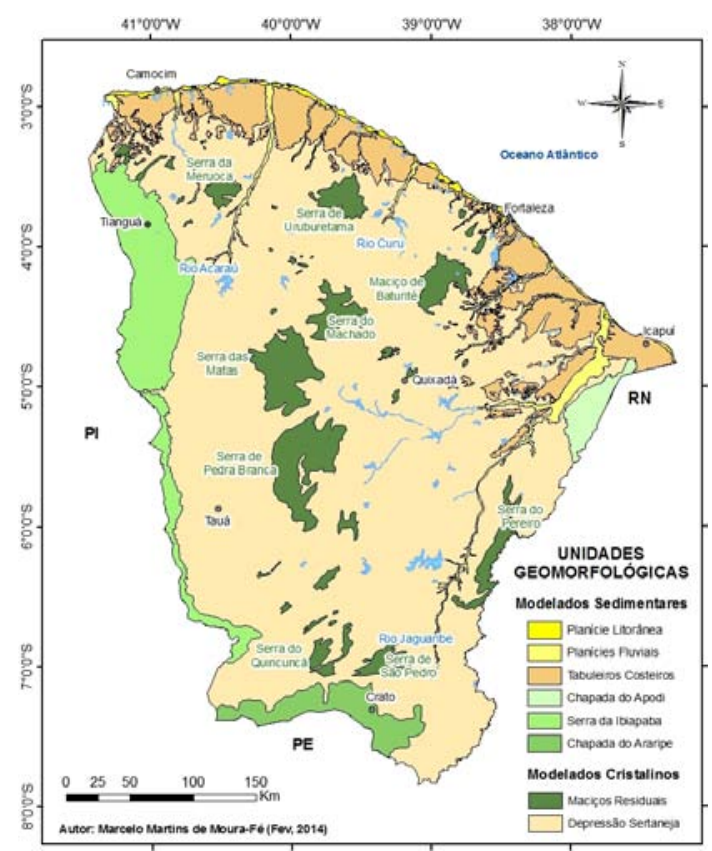

Figura 2 - Mapa geomorfológico simplificado do Ceará. Fonte: Mapa Geológico do Estado do Ceará (CPRM, 2003), cartas topográficas (SUDENE 1999), imagem SRTM e informações de levantamentos de campo. Figure 2 - Simplified geomorfological map of Ceará state. Sources used to produce the map: geological map of Ceará state (CPRM, 2003), topographic charts (SUDENE 1999), SRTM images and fieldwork done by the author. que produziram, em última instância, a ruptura dos continentes sul-americano e africano. Isso resultou no soerguimento das feições pretéritas (Depressão Sertaneja, Serra da Ibiapaba e os maciços residuais), originando o eixo estrutural Cariri-Potiguar. A formação das respectivas bacias e das Chapadas do Araripe e do Apodi (130-125 milhões de anos antes do presente) deram origem à configuração atual da linha de costa cearense (Matos 1992; Matos 2000; Peulvast \& Claudino-Sales 2004; Peulvast \& Claudino-Sales 2006).

Ao curso do Terciário e do Quaternário o território do Ceará passou por diversas variações climáticas e eustáticas, com a deposição da Formação Barreiras e a modelagem dos tabuleiros costeiros, a macro-configuração da rede de drenagem, e a modelagem de formas costeiras, tais como praias, estuários, lagoas e dunas (Arai 2006; Bezerra et al. 2001; Claudino-Sales 2002).

No que diz respeito à geologia, podemos considerar que o Ceará possui basicamente dois grandes domínios geológicos: um sedimentar e outro com predomínio de litologias cristalinas. Sobre esses domínios foram modelados diferentes tipos de relevo do estado. Em um exercício de síntese, poderíamos considerar três grandes subdivisões principais do relevo ao tomar o estado como um imenso anfiteatro, no qual as chapadas interiores circundam a extensão da depressão sertaneja, na qual se elevam diversos maciços residuais, e que, por sua vez, é bordejada pelas feições litorâneas, de origem sedimentar.

Ao observarmos com atenção a compartimentação da geomorfologia cearense (Fig. 2), teremos seis unidades de relevo modeladas em substrato sedimentar (Planície Litorânea, Planícies Fluviais, Tabuleiros Costeiros, Chapada do Apodi, Serra da Ibiapaba e Chapada do Araripe) e duas unidades modeladas em substrato cristalino (Maciços Residuais e Depressão Sertaneja).

No decorrer do texto, partiremos da descrição dessas unidades de relevo por entender que aos diversos ambientes por elas condicionados estão associados diferentes tipos de vegetação. A Figura 2 traz um mapa geomorfológico simplificado e a Figura 3 um mapa do sistema de unidades fitoecológicas do estado do Ceará. Ambas têm o propósito de nortear o entendimento no que tange à relação entre as diferentes fitofisionomias e as unidades de relevo do território cearense 
Tabela 1 - Unidades de relevo e tipos de vegetação do estado do Ceará, com a área aproximada de cada Unidade Fitoecológica.

Table 1 - Geomorphological units and vegetation types of Ceará state, northeastern Brazil, showing the approximate area occupied by each Phytoecological Unit.

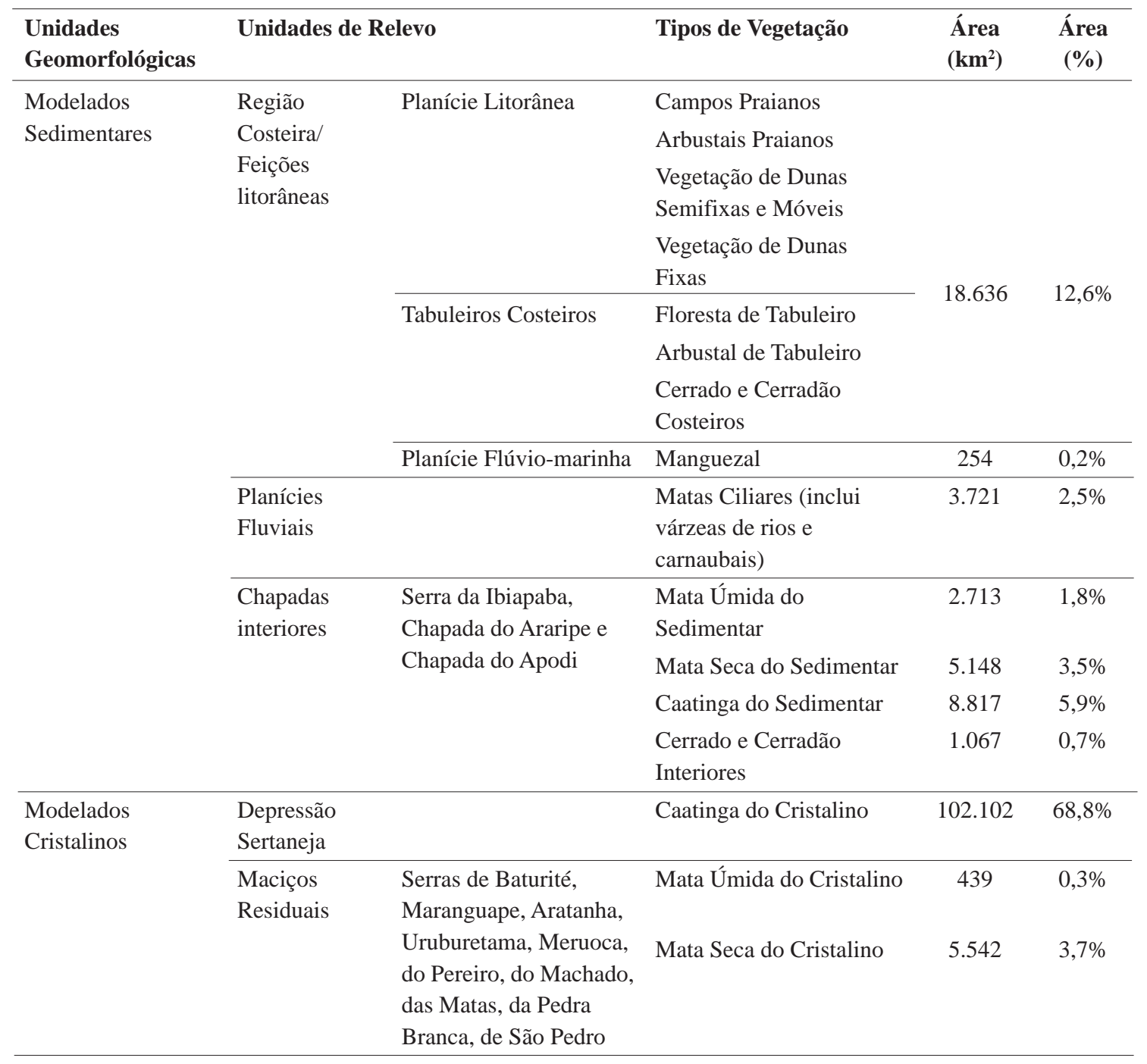

Total do estado do Ceará

148.439* $100 \%$

* A área total obtida pelo somatório da extensão de cada tipo de vegetação não equivale exatamente à área oficial do estado do Ceará $\left(148.825,60 \mathrm{~km}^{2}\right)$ devido a imprecisões na extensão geográfica do mapeamento das unidades fitoecológicas feito para o Atlas do Ceará nas décadas de 1980 e 1990 (ver Figueiredo 1997). Portanto, a área de cada unidade fitoecólogica calculada aqui deve ser tomada apenas como uma aproximação. Devido à escala de mapeamento e a imprecisões cartográficas, a área de vegetações de menor extensão como manguezais, matas ciliares e matas secas e úmidas não podem ser tomadas como estimativas precisas.

(consultar também a Tabela 1 e o Apêndice 4). No Apêndice 1 e no Suplemento Digital 1 (<http:// dx.doi.org/10.6084/m9.figshare.1289920>) o leitor encontrará um pequeno acervo fotográfico das vegetações do estado, a fim de complementar a compreensão dessa diversidade paisagística.
Tomando como referência os elementos climáticos e geomorfológicos aqui elencados, propomos a seguir uma caracterização das fitofisionomias do estado do Ceará e dos seus principais constituintes florísticos a partir de suas diversas unidades de relevo. 
Unidades fitoecológicas do Ceará: uma caracterização a partir da relação vegetação-geomorfologia

\section{Região Costeira/Feições Litorâneas}

Geograficamente a região costeira do Ceará é delimitada pela ocorrência dos afloramentos da Formação Barreiras. A Formação Barreiras é o substrato geológico de um relevo plano, caracterizado amplamente como tendo origem sedimentar, formado durante o TerciárioQuaternário pelos sedimentos derivados da erosão do continente. Geralmente é conhecida pela feição dos tabuleiros costeiros e se limita com o oceano Atlântico ao norte, com a Chapada do Apodi a leste, com a Serra da Ibiapaba a sudoeste e com a Depressão Sertaneja ao sul.

A região costeira é uma das regiões fitoecológicas mais complexas propostas por Figueiredo (1997), pois agrega um conjunto vegetacional diversificado submetido a condições ecológicas bastante diferenciadas: de manguezais a matas de tabuleiro, passando por cerrados costeiros e campos praianos. A região costeira do Ceará tem uma origem geológica recente (TerciárioQuaternário) e sua flora é constituída tipicamente por espécies dos domínios fitogeográficos circundantes (Cerrado, Caatinga e Mata Atlântica), somadas a espécies típicas de vegetação praiana (restingas).

A mata de tabuleiro (floresta estacional semidecídua dos tabuleiros costeiros) e os cerrados costeiros, por exemplo, agregam espécies vindas dos Domínios do Cerrado e da Caatinga. Por outro lado, boa parte das espécies que ocorrem nos manguezais (Rhizophora mangle, Laguncularia racemosa, etc) e nos campos praianos (Remirea maritima, Ipomoea pes-caprae) são específicas de ambientes costeiros, e embora tenham ampla dispersão nos ambientes costeiros do Brasil, são restritas a esse tipo de ambiente.

No macroambiente costeiro, definido como aquele sob influência da Formação Barreiras, encontramos dois "ambientes edáficos" principais: o que se localiza diretamente sobre a Formação Barreiras e o que se localiza sobre as areias quartzosas, nos campos de dunas e na beira das praias (planície de deflação).

Sobre a Formação Barreiras podemos encontrar duas vegetações principais: a mata de tabuleiro e os cerrados costeiros. A mata de tabuleiro é uma floresta estacional semidecídua de médio porte (Castro et al. 2012) e é a vegetação mais amplamente dispersa sobre a Formação Barreiras. Os cerrados costeiros são áreas savânicas que ocorrem sobre a Formação Barreiras como manchas disjuntas de vegetação e onde há uma predominância de espécies do Cerrado na comunidade lenhosa (Moro et al. 2011, Fig. 3). O regime de fogo também parece ser um fator importante. Áreas submetidas a incêndios frequentes adquirem fisionomia savânica e as plantas típicas do bioma Cerrado, mais resistentes ao fogo, aumentam suas populações, constituindo as áreas de cerrados costeiros (Moro et al. 2011). Já nas áreas protegidas do fogo a vegetação se torna florestal e as espécies resistentes ao fogo, embora presentes na comunidade, reduzem sua densidade. Um exemplo é o contraste entre as populações de janaguba (Himatanthus drasticus), uma espécie de cerrado tolerante ao fogo, entre o cerrado costeiro (Moro et al. 2011) e a mata de tabuleiro (Castro et al. 2012). Embora presente nas duas áreas, $H$. drasticus e outras espécies tolerantes ao fogo têm uma densidade bem menor na mata de tabuleiro em relação ao cerrado costeiro. Trata-se de um padrão bem conhecido que a estrutura da vegetação do Cerrado muda com o aumento dos incêndios, tornando-se savânica quando há incêndios frequentes e florestal quando há redução do regime de fogo (Libano \& Felfili 2006; Medeiros \& Miranda 2008; Pinheiro \& Durigan 2009). É provável que diferentes tipos de solo da Formação Barreiras gerem a diferenciação observada entre mata de tabuleiro e os cerrados costeiros, mas ainda não há dados consistentes para confirmar esta hipótese.

Além de florestas e cerrados, há outra formação nos tabuleiros, de distribuição mais restrita. Em áreas de falésias, onde a Formação Barreiras se aproxima do mar, há um arbustal sobre os tabuleiros (ou em inglês scrubland, uma vegetação de porte arbustivo) composto por espécies típicas de caatinga (como Commiphora leptophloeos e Aspidosperma pyrifolium) e Cactáceas (especialmente Cereus jamacaru e Pilosocereus catingicola subsp. salvadorensis) que assumem porte mais baixo e esparso que na caatinga. Essa formação não é referida em Figueiredo (1997), por ocupar uma área de ocorrência menor que a mata de tabuleiro e cerrados costeiros, mas é comumente encontrada sobre falésias ou eventualmente na planície de deflação (feição embutida no contexto da planície litorânea), próxima ao mar. 
Sobre as areias quartzosas próximas ao mar (beira de praia) ou nos campos de dunas podemos encontrar a chamada vegetação psamófila (ou “amiga de ambientes arenosos”). Trata-se de uma vegetação predominantemente herbácea, com espécies resistentes à alta salinidade, escassez de nutrientes do solo, altas temperaturas, alta insolação e elevada mobilidade da areia. Comumente são herbáceas estoloníferas, somadas a algumas poucas plantas lenhosas como o guajiru (Chrysobalanus icaco). A vegetação pioneira psamófila se desenvolve tipicamente sobre a planície de deflação (contato externo da faixa de praia) e nas dunas móveis.

Já nos campos de dunas fixas encontramos uma vegetação diferente. As areias quartzosas são um ambiente difícil de colonizar, mas com o passar do tempo algumas plantas mais resistentes como o cajueiro (Anacardium occidentale), murici (Byrsonima crassifolia) e herbáceas das famílias Poaceae, Cyperaceae, Convolvulaceae, Boraginaceae e Fabaceae vão tornando a duna menos móvel até atingir o estágio de duna semifixa. Paulatinamente, com a evolução do processo e o início da pedogênese (formação do solo), mais espécies colonizam o ecossistema até formar os arbustais e florestas de dunas fixas. Nesse ponto, as dunas não mais migram e a riqueza em espécies aumenta.

Devido à diversidade de formações que coocorrem na região costeira e devido à origem da flora (composta por espécies migrantes das vegetações e domínios fitogeográficos circundantes), Figueiredo (1997) propôs a expressão "Complexo Vegetacional da Zona Litorânea” para agregar todos os ambientes e todas as fitofisionomias da região costeira (da Formação Barreiras até a beira mar). Os principais tipos de ambiente do Complexo Vegetacional da Zona Litorânea, abreviado aqui para Complexo Vegetacional Costeiro, e sua flora são discutidos em mais detalhes adiante.

Nas áreas litorâneas, a implantação de grandes empreendimentos turísticos e de projetos de grande impacto ambiental, como o complexo

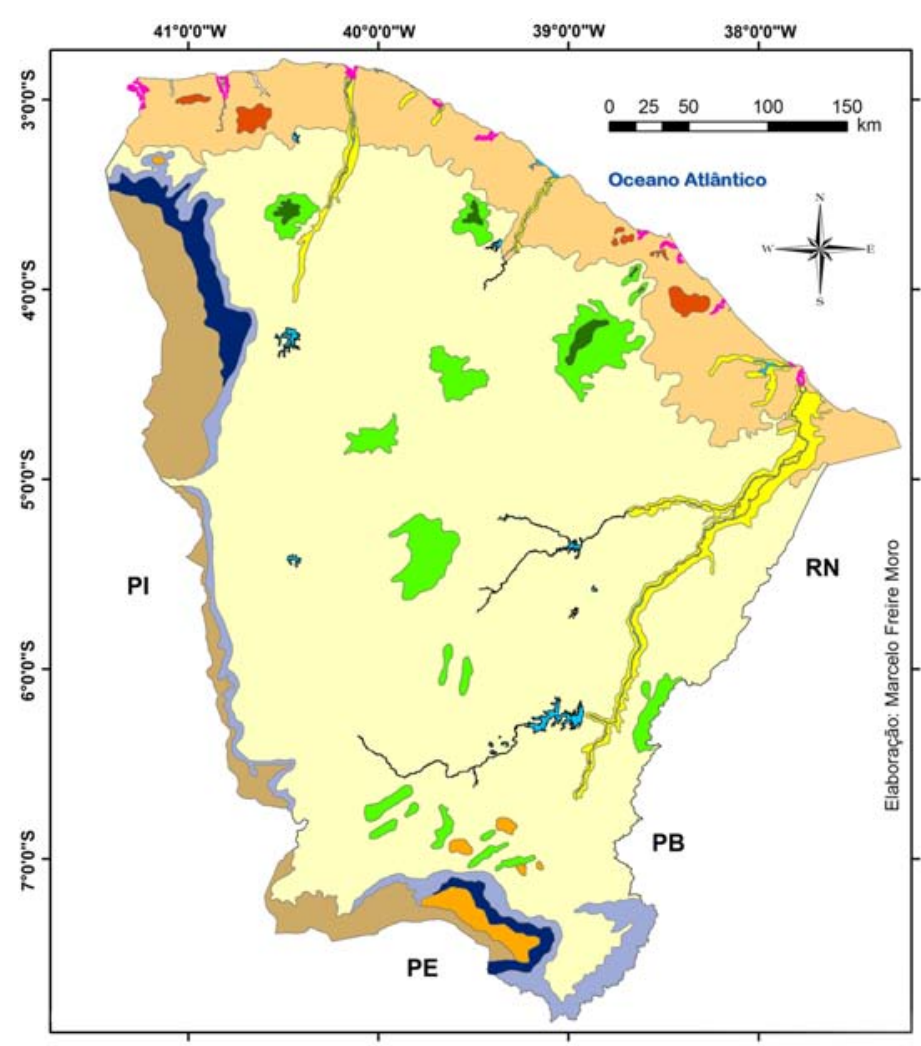

\section{Unidades fitoecológicas do Ceará (modificado de Figueiredo 1997)}

Complexo Vegetacional Costeiro

Manguezal

Cerrado e Cerradão Costeiros

Cerrado e Cerradão Interiores

Carnaubal

Caatinga do Cristalino

Mata Seca do Cristalino

Mata Úmida do Cristalino

Caatinga do Sedimentar

Mata Seca do Sedimentar

Mata Úmida do Sedimentar

$\sum$ Corpos Hidricos

Figura 3 - Mapa de Unidades Fitoecológicas do Ceará. Fonte: Modificado a partir do Mapa de Unidades Fitoecológicas do Ceará do IPLANCE (Figueiredo 1997).

Figure 3 - Map showing the phytoecological units ofCeará state. Source: Modified from the Phytoecological Map of Ceará state (Figueiredo 1997). 
industrial do Pecém, além da expansão urbana, são as maiores ameaças atualmente. As ações orientadas ao planejamento da atividade turística desenvolvem a ocupação calculada dos territórios costeiros, visando integrá-los aos interesses de grandes grupos econômicos e, dessa forma, se tornam uma ameaça bastante pungente, já que têm promovido a destruição dos ecossistemas costeiros e do modo de vida tradicional das populações humanas costeiras do estado (Lima \& Meireles 2006; Nascimento 2006; Araújo \& Moura 2007).

\subsection{Planície Litorânea: Campo Praiano e Arbustal Praiano, Vegetação de Dunas Semifixas e Móveis, Vegetação de Dunas Fixas}

A planície litorânea (Fig. 2) corresponde a uma faixa contínua na orla marítima entre o mar e os tabuleiros costeiros, interrompida apenas pelas desembocaduras dos rios que chegam ao oceano. Embutidas na planície litorânea estão diversas feições geomorfologicamente muito dinâmicas e instáveis, tais como as praias, as dunas móveis (que não apresentam desenvolvimento pedológico), e as dunas fixas (situadas nas partes mais internas da costa e recobertas por vegetação desenvolvida sobre os neossolos quartzarênicos).

É formada pela acumulação recente de sedimentos Holocênicos e apresenta uma estrutura de baixa inclinação definida pela interação dos agentes constituintes do processo. Esta interação resulta numa configuração morfológica predominantemente plana a suave ondulada, que se modifica nas áreas de campos de dunas e planícies de deflação, onde o relevo mostra-se mais irregular e elevado (Moura-Fé 2008). O conjunto das vegetações de dunas (fixas, semifixas e móveis), de arbustais e de campos praianos equivale ao que no resto do Brasil comumente se chama de vegetação de restinga, embora o termo vegetação de restinga não seja muito comum na literatura botânica cearense.

\section{- Campo Praiano e Arbustal Praiano}

Logo após a faixa de marés (praia), a planície costeira do Ceará é constituída por areias quartzosas que são constantemente retrabalhadas pelo vento e pelo mar: a planície de deflação, também referida na literatura como pós-praia ou anteduna. Esse ambiente, assim como as dunas móveis, é altamente limitante para as plantas e ainda apresenta um fator extra de estresse: os sprays marinhos e a maresia, resultantes das ondas do mar e da ação do vento, tornam este ambiente salino. Nesse ambiente instável de areias quartzosas se desenvolve o campo praiano, com espécies herbáceas especializadas como Ipomoea pes-caprae, Remirea maritima e Sesuvium portulacastrum, que são espécies praticamente restritas a ambientes arenosos e salinos da costa. Poucas são as arbustivas, podendo ser citadas Scaevola plumieri e Guilandina bonduc. As espécies que suportam este ambiente estressante têm ampla dispersão nas regiões costeiras do Brasil e são tipicamente características dos campos praianos. Em alguns locais da costa, há, além do campo, um arbustal praiano onde a vegetação psamófila atinge porte arbustivo composto por espécies lenhosas resistentes ao ambiente arenoso e salino.

As ameaças à conservação são especialmente o crescimento urbano.

Espécies características: Blutaparon portulacoides, Canavalia rosea, Fimbristylis cymosa, Guilandina bonduc, Ipomoea pes-caprae, Panicum racemosum, Paspalum vaginatum, Remirea maritima, Scaevola plumieri, Sesuvium portulacastrum, Sporobolus virginicus, Turnera melochioides.

- Vegetação de Dunas Semifixas e Móveis

As dunas semifixas e móveis são a geração mais recente de dunas, que ainda não foram fixadas pela vegetação. Em grande medida são desprovidas de cobertura vegetal, embora algumas plantas muito resistentes cresçam nas areias quartzosas, pobres em nutrientes e altamente móveis. Nas dunas semifixas e móveis, o processo de pedogênese ainda não se iniciou e, devido ao ambiente hostil, poucas espécies conseguem se estabelecer. Nas dunas semifixas, moitas de Anacardium occidentale e Byrsonima crassifolia iniciam o processo de fixação das dunas, embora elas ainda sejam, nesse estágio, majoritariamente móveis, praticamente descobertas de vegetação e ocupadas predominantemente por espécies herbáceas (e.g. Stilpnopappus trichospiroides e Chamaecrista ramosa) e arbustivas resistentes. A espécie invasora Calotropis procera também consegue se estabelecer nesse ambiente.

Tanto a vegetação de dunas móveis e semifixas quanto a vegetação de beira de praia são denominadas por Figueiredo (1997) como Vegetação Pioneira Psamófila, porque o ambiente geológico é muito recente e as plantas que aqui ocorrem são apenas aquelas capazes de suportar 
alto grau de irradiação solar e mobilidade dos sedimentos (o termo psamófila se refere ao ambiente arenoso). Levantamentos publicados acerca da vegetação de dunas móveis e semifixas estão disponíveis em Matias \& Nunes (2001) e Castro et al. (2012).

As ameaças à conservação são as mesmas apresentadas para o complexo vegetacional costeiro, somadas à extração de areia para construção civil. Contudo, as ameaças derivadas da expansão urbana desordenada, a construção de estradas sobre as dunas e a instalação de resorts e campos de golfe, são as ameaças mais graves.

Espécies características: Anacardium occidentale, Byrsonima crassifolia, Centrosema rotundifolium, Chamaecrista hispidula, Chamaecrista ramosa, Chrysobalanus icaco, Cyperus maritimus, Elephantopus hirtiflorus, Indigofera microcarpa, Ipomoea asarifolia, Macroptilium panduratum, Pombalia calceolaria, Stilpnopappus trichospiroides.

\section{- Vegetação de Dunas Fixas}

Enquanto os tabuleiros têm um substrato de origem Terciária, os campos de dunas são bem mais recentes, datando do Quaternário. As dunas do Ceará podem ser divididas em diferentes gerações, das quais as dunas fixas são as mais antigas, de modo que já foram ocupadas pela vegetação. A fixação da vegetação acaba por iniciar o processo de pedogênese e acumulação de matéria orgânica no solo. Faltam estudos florísticos nas dunas fixas, mas a flora dessa formação parece ser um subconjunto da flora dos tabuleiros (veja a lista florística de Castro et al. 2012). Por serem de origem geológica recente, as dunas fixas não possuem flora endêmica.

Dunas fixas podem apresentar vegetação rasteira, constituindo um campo de dunas, ou podem ser ocupadas de modo consistente por plantas lenhosas, formando um arbustal ou uma floresta de pequeno a médio porte, situações em que a Vegetação de Dunas Fixas pode ser discriminada entre os Campos de Dunas Fixas, Arbustais de Dunas Fixas e Florestas de Dunas Fixas.

As ameaças à conservação são as mesmas apresentadas no tópico do complexo vegetacional costeiro. Contudo, a expansão urbana desordenada, a construção de estradas e o turismo (sobretudo com instalação de resorts), são as ameaças mais graves (Lima \& Meireles 2006). Na região de Fortaleza, essa formação é altamente ameaçada pela pressão da ocupação imobiliária, uma vez que as últimas áreas de dunas fixas do município estão na região do Cocó e, portanto, apresentam alto valor imobiliário, sendo significativa a pressão econômica para que estas áreas sejam desmatadas para dar lugar a condomínios urbanos.

Espécies características: Anacardium occidentale, Byrsonima crassifolia, Byrsonima gardneriana, Chamaecrista ensiformis, Chioccoca alba, Chloroleucon acacioides, Chrysophyllum arenarium, Copaifera arenicola, Eugenia luschnathiana, Guettarda angelica, Maclura tinctoria, Senna rizzinii, Strychnos parvifolia, Ximenia americana.

\subsection{Planície Flúvio-marinha: Manguezal - Manguezal}

Os manguezais são florestas paludosas especializadas em um ambiente específico: as regiões estuarinas tropicais, mais precisamente nas planícies flúvio-marinhas (Figs. 2; 3).

Caracterizadas pela ação conjunta de processos continentais e marinhos, as planícies flúvio-marinhas são ambientes originados da deposição de sedimentos dominantemente argilosos e ricos em matéria orgânica, onde se desenvolve a vegetação de mangue. São formadas em áreas onde se processa a mistura de água doce dos rios e lagoas, com a água salgada que penetra o continente através das marés (Brandão 1995). O resultado desta mistura proporciona a deposição de material escuro e argiloso, que aumenta a cada período de maré cheia, até gerar o ambiente favorável à instalação dos manguezais.

Manguezais são ecossistemas encontrados por todos os trópicos na foz dos rios. Um fator ecológico fundamental na compreensão dos manguezais é que o fluxo das marés gera mudanças diárias no nível de água e no nível de salinidade. Quando a maré sobe, a água do mar vence a pressão feita pelas águas do rio e penetra a região estuarina, inundando parte do ambiente e tornando a água mais salgada. Quando a maré desce, a água do mar recua, expondo ao ar atmosférico áreas antes inundadas e permitindo que a água doce do rio prevaleça, reduzindo a salinidade da água.

Devido ao ambiente lamoso e solos ricos em enxofre (tiomórficos), submetidos ao ciclo diário de cheia-vazante-cheia e ao ciclo de aumento e redução da salinidade da água resultante do movimento das marés, os manguezais são ambientes difíceis de serem ocupados pelas 
plantas. Um grupo de espécies halófilas evoluiu para suportar tais condições e se tornou altamente especializado nesse ambiente. A flora dos manguezais americanos é tipicamente composta por árvores e arbustos dos gêneros Rhizophora, Laguncularia, Avicennia e Conocarpus, somadas a espécies herbáceas especializadas das famílias Aizoaceae e Amaranthaceae.

No ecossistema de manguezal há um subtipo específico de ambiente chamado "apicum" ou salgado. Enquanto o manguezal propriamente dito é uma vegetação florestal, os apicuns são campos arenosos nos quais predomina uma vegetação herbácea adaptada a ambientes salinos. Há uma dinâmica de expansão e retração dos manguezais e apicuns, de modo que ambos devem ser considerados como um macroambiente de "manguezal", contendo os ambientes de apicum e floresta de mangue. Um levantamento florístico das espécies de apicum e floresta de mangue está disponível em Castro et al. (2012).

Embora seja um ambiente limitante para muitas espécies de plantas, o manguezal é um berçário para a vida animal. As águas eutróficas permitem à fauna obter alimentação abundante nas regiões estuarinas. Com isso, vários peixes, crustáceos e mamíferos aquáticos frequentam os estuários para se reproduzir ou se alimentar, tornando os manguezais um ecossistema de extrema importância para o ambiente marinho.

No Brasil, os Manguezais são protegidos por lei, mas com a introdução da aquicultura e da carcinicultura no Nordeste a pressão de desmatamento para a construção de tanques de criação de camarão se tornou muito grande. Projetos de desmatamento de manguezais, drenagem de partes dos estuários e construção de tanques de aquicultura, embora proibidos por legislação federal, foram incentivados e devidamente licenciados pelos governos estaduais (do Ceará inclusive) resultando em graves impactos a estes ecossistemas, com apoio do poder público. Um problema colateral gerado pela aquicultura é que essa atividade, ao descartar a água contaminada utilizada nos tanques, libera no ambiente poluentes e antibióticos, prejudicando o manguezal, além de potencialmente introduzir espécies exóticas que podem se tornar invasoras.

Espécies características: Floresta de mangue: Acrostichum aureum, Avicennia germinans, Conocarpus erectus, Laguncularia racemosa, Rhizophora mangle. Apicuns: Ammannia latifolia,
Bacopa cochlearia, Batis maritima, Blutaparon portulacoides, Fimbristylis spadicea, Sesuvium portulacastrum, Sporobolus virginicus.

\subsection{Tabuleiros Costeiros: Mata de Tabuleiro, Arbustal de Tabuleiro e Cerrado Costeiro}

Os tabuleiros costeiros (Fig. 2) bordejam a faixa costeira cearense. São relevos planos, intercalados com trechos suave-ondulados e apresentam uma amplitude altimétrica resultante, especialmente, da erosão dos rios. Esse ambiente é constituído sobretudo pelos sedimentos da Formação Barreiras, e apresenta o desenvolvimento dos argissolos vermelho-amarelos. Esses solos são os mais amplamente distribuídos no Ceará, encontrados em áreas de relevo plano a montanhoso.

Modelados no topo dos sedimentos da Formação Barreiras, os tabuleiros costeiros são, na verdade, formas tabulares estruturais, isto é, relevos cujo modelado expressa de forma relativamente fiel a estrutura geológica (Moreira \& Gatto 1981; Claudino-Sales 2002; Claudino-Sales 2005) e a forma geral pela qual os pacotes sedimentares foram depositados (Moura-Fé 2008).

Em média, os tabuleiros penetram cerca de 40 $\mathrm{km}$ para o interior (Souza 1988), mas podem chegar a $90 \mathrm{~km}$ em direção ao continente (ClaudinoSales 1993). Os tabuleiros apresentam níveis altimétricos que variam desde 80 a 100 metros nas partes mais internas do continente, até o nível do mar, mergulhando sempre de maneira suave, quase imperceptível, para o litoral, com declives inferiores ou iguais a $5^{\circ}$ (Souza 1988).

\section{- Mata de Tabuleiro}

Sobre os tabuleiros, em áreas não atingidas por incêndios frequentes, podemos encontrar uma floresta semidecídua de médio porte chamada de mata ou floresta de tabuleiro (Fig. 3). Dentre as formações costeiras é a mais rica em espécies lenhosas, com uma flora que mistura elementos do Cerrado, Caatinga, Mata Atlântica e até mesmo Amazônia (e.g. Coccoloba latifolia) (Castro et al. 2012).

A mata de tabuleiro do Ceará não é equivalente às matas de tabuleiro da Bahia e do Espírito Santo. Enquanto nesses estados o tabuleiro recebe alta pluviosidade e apresenta vegetação ligada à Mata Atlântica, os tabuleiros do Ceará estão em climas bem mais secos, variando de subúmidos a semiáridos. Aqui predominam espécies capazes de resistir a uma sazonalidade mais prolongada que na Mata Atlântica e menos prolongada que na Caatinga, o que pode 
explicar a miscelânea de espécies de outros domínios fitogeográficos que ocuparam esse ambiente.

Devido à sua origem geológica relativamente recente (a Formação Barreiras tem idade semelhante à do Pantanal), os tabuleiros (assim como o Pantanal) não têm, de modo geral, uma flora endêmica característica, mas sim, uma flora colonizadora oriunda das vegetações adjacentes. De fato, encontramos espécies do Domínio do Cerrado que colonizaram tanto a bacia sedimentar costeira do Ceará quanto a bacia pantaneira e hoje fazem parte da flora desses dois ambientes. Exemplos são Genipa americana, Tabebuia aurea, Curatella americana e Anacardium occidentale, os quais são elementos do Domínio do Cerrado presentes tanto no Pantanal quanto na mata de tabuleiro cearense. Castro et al. (2012) apresentaram um levantamento florístico e um piloto de levantamento fitossociológico para a mata de tabuleiro cearense.

As ameaças à conservação são as mesmas mencionadas no tópico do complexo vegetacional costeiro.

Espécies características: Agonandra brasiliensis, Anacardium occidentale, Byrsonima crassifolia, Byrsonima gardneriana, Chamaecrista ensiformis, Curatella americana, Handroanthus impetiginosus, Himantanthus drasticus, Hirtella ciliata, Hirtella racemosa, Manilkara triflora, Mouriri cearensis, Myrcia splendens, Ouratea fieldingiana, Pilosocereus catinguicola subsp. salvadorensis, Tapirira guianensis, Zanthoxylum syncarpum.

\section{- Arbustal de Tabuleiro}

É uma vegetação de porte arbustivo que ocorrem em alguns trechos dos tabuleiros costeiros, especialmente em áreas de falésias, bem próximas ao mar. Espécies típicas da caatinga do cristalino e algumas Cactáceas co-ocorrem nessas áreas. Matas de tabuleiro degradadas antropicamente também podem originar arbustais costeiros.

Espécies características: Anacardium occidentale, Byrsonima crassifolia, Commiphora leptophloeos, Cereus jamacaru, Pilosocereus catinguicola subsp. salvadorensis.

\section{- Cerrado Costeiro}

Nas áreas dos tabuleiros costeiros sujeitas a incêndios mais frequentes, a vegetação assume uma fisionomia savânica (Moro et al. 2011). Nessas áreas, espécies oriundas do Domínio do Cerrado predominam em locais próximos à costa, por isso o nome de savanas ou cerrados costeiros (Fig. 3). Apesar da predominância de espécies do Cerrado, espécies do Domínio da Caatinga, como Croton blanchetianus, também ocorrem nestas comunidades. O cerrado costeiro não é restrito ao Ceará. Manchas dessa formação já foram estudadas no Ceará (Moro et al. 2011), Rio Grande do Norte (Oliveira et al. 2012) e na Paraíba (Oliveira-Filho \& Carvalho 1993). Mais informações sobre a vegetação de cerrado no Ceará são apresentadas mais abaixo, no tópico específico para essa formação.

As ameaças à conservação são as mesmas apresentadas no tópico sobre o complexo vegetacional costeiro. No município de Fortaleza, essa formação é altamente ameaçada pela pressão de ocupação imobiliária, uma vez que apenas uma mancha de cerrado costeiro é conhecida na cidade, na região do Cambeba (Moro et al. 2011; Fortaleza 2003), em um local com sérios riscos à conservação devido à pressão de urbanização.

Espécies características: Anacardium occidentale, Annona coriacea, Byrsonima crassifolia, Curatella americana, Himantanthus drasticus, Hirtella ciliata, Hirtella racemosa, Leptolobium dasycarpum, Simarouba versicolor, Stryphnodendron coriaceum, Tapirira guianensis.

\section{Planícies Fluviais: Mata Ciliar / Carnaubal}

As Planícies Fluviais são constituídas por sedimentos de idade Quaternária e apresentam tamanhos e extensões diferenciadas, condicionadas pela vazão dos rios associados. No Ceará destacamse as planícies dos rios Coreaú, Acaraú, Curu, Jaguaribe e Choró. Os solos típicos desses setores, ao longo dos grandes rios, são os neossolos flúvicos, os quais podem alcançar grandes profundidades, permitindo o desenvolvimento de matas ciliares associadas à carnaúba (Copernicia prunifera), constituindo os carnaubais.

\section{- Mata Ciliar}

Ao longo do curso dos rios do semiárido, desenvolvem-se florestas de porte maior que a vegetação circundante, as chamadas matas ciliares. Essas matas crescem sobre solos mais profundos que os terrenos cristalinos da Depressão Sertaneja e possuem árvores perenifólias como Ziziphus joazeiro, Licania rigida e Vitex gardneriana. Às margens dos rios de maior porte formam-se planícies fluviais mais extensas, constituindo faixas (por vezes com muitas dezenas de metros de 
largura) de planícies com neossolos flúvicos que acompanham o leito dos rios, devido ao depósito de sedimentos carreados por esses rios. Nessas planícies desenvolve-se uma vegetação ripária com marcante presença de carnaúba (Copernicia prunifera), constituindo um tipo particular de mata ciliar que recebe o nome de mata ciliar com carnaúba ou carnaubal, descrito abaixo.

\section{- Carnaubal (mata ciliar com carnaúba)}

Figueiredo (1997) considerou os carnaubais como uma unidade fitoecológica distinta. Já AndradeLima (1981) considerou os carnaubais um subtipo de caatinga. De fato, os carnaubais crescem em um ambiente diferente das caatingas típicas, pois se desenvolvem nas planícies fluviais que bordejam os rios cearenses, possuindo solos diferenciados daquele das caatingas típicas.

Os carnaubais constituem a vegetação típica que margeia os leitos dos grandes rios do semiárido brasileiro, embora possam ocorrer também ao redor de outros corpos hídricos como lagoas e lagunas. Geralmente crescem sobre os neossolos flúvicos, hidromorfos, plásticos, sujeitos a inundações durante parte do ano. Os carnaubais ocorrem no Ceará desde áreas semiáridas do interior até regiões subúmidas costeiras, associados aos leitos de rios, lagoas ou áreas periodicamente inundáveis. Na costa, os carnaubais podem aparecer tanto como agrupamentos ao redor de lagoas e riachos costeiros, quanto como uma extensão geográfica dos carnaubais que vêm do interior, a exemplo dos carnaubais que acompanham os rios Jaguaribe, Acaraú e Coreaú. Em uma síntese dos levantamentos florísticos e fitossociológicos feita sobre o semiárido brasileiro (Moro et al. 2014a; Moro et al. 2015), os carnaubais foram uma das unidades menos estudadas do Domínio das Caatingas. Com isso, faltam subsídios para compreender melhor sua flora. Embora os carnaubais sejam uma formação bastante disseminada pelo território cearense, praticamente não há estudos florísticos ou fitossociológicos consistentes sobre os mesmos. Um levantamento florístico em um carnaubal costeiro está disponível em Castro et al. (2012). Estudos florísticos e fitossociológicos em carnaubais das regiões semiáridas típicas são altamente desejáveis.

Devido ao valor econômico da cera extraída da folha das carnaúbas, o extrativismo desta planta se tornou uma atividade econômica importante no Nordeste e, atualmente, a maioria dos carnaubais tem seu sobosque cortado e queimado (um processo chamado de "limpeza do terreno"), deixando-se apenas as carnaúbas para extração futura. Com isso, a maioria dos carnaubais do estado passou por histórica deterioração antrópica. O desmatamento, a ocupação das margens dos rios e o crescimento urbano em leitos de inundação dos rios são outras ameaças à conservação desses ecossistemas, junto com o extrativismo intenso. Na região costeira, a implantação de grandes empreendimentos turísticos e do complexo industrial do Pecém também representam ameaça, já que são empreendimentos de alto impacto ambiental, incentivados pelo governo do estado.

Espécies características: Combretum laxum, Copernicia prunifera, Erythrina velutina, Ficus elliotiana, Geoffroea spinosa, Guazuma ulmifolia, Licania rigida, Maytenus obtusifolia, Sapindus saponaria, Sebastiania macrocarpa, Tarenaya spinosa, Ziziphus joazeiro.

\section{Depressão Sertaneja: Caatinga do Cristalino}

ADepressão Sertaneja éuma superfície cristalina bastante erodida, formada predominantemente por rochas do Pré-Cambriano - Paleoproterozóico e Neoproterozóico. Ocupa quase $70 \%$ do território cearense e faz contato geográfico com todas as demais unidades geomorfológicas do estado (Souza 1988). A depressão sertaneja vem sendo modelada há muito tempo sobre as litologias mais antigas do Ceará, condicionando seus níveis altimétricos, majoritariamente inferiores a $400 \mathrm{~m}$, embora alguns maciços cristalinos residuais (serras cristalinas - ver abaixo) atinjam cotas altimétricas maiores. Correspondendo a uma superfície de aplainamento, a Depressão Sertaneja é modelada sobre as rochas cristalinas, onde o trabalho erosivo truncou indistintamente variados tipos litológicos. A morfologia da Depressão Sertaneja é representada por extensas rampas pedimentadas que se iniciam na base dos maciços residuais e se inclinam suavemente em direção aos fundos de vales e ao litoral (Souza 1988).

Por conta da deficiência hídrica característica da região, a Depressão Sertaneja apresenta classes de solos pouco desenvolvidas, isto é, solos rasos, a exemplo dos luvissolos, pouco profundos, frequentemente contendo pedregosidade superficial e comumente recobertos por vegetação de caatinga do cristalino.

\section{- Caatinga do Cristalino}

A caatinga do cristalino é o tipo de vegetação típica da Depressão Sertaneja. É decídua, espinhosa e adaptada ao clima semiárido, com apenas 
poucas espécies perenifólias (e.g. Ziziphus spp., Cynophalla spp., Licania rigida, Libidibia ferrea). Como a pluviosidade é concentrada em apenas alguns meses, durante boa parte do ano as plantas não possuem água disponível para seu crescimento. Com isso, a maioria das árvores e arbustos evitam o estresse hídrico descartando as folhas durante a estação seca. Já as ervas são em sua maioria anuais, ou seja, possuem forma de vida terofítica.

Além dos fatores climáticos, fatores edáficos também determinam a ocorrência da caatinga. Estudos biogeográficos (Cardoso \& Queiroz 2007; Gomes et al. 2006; Costa et al. 2007) têm demonstrado que o que chamamos de caatinga deve ser dividido em dois grandes grupos florísticos: a caatinga das áreas sobre o embasamento cristalino (caatinga do cristalino, também referida na literatura como caatinga sensu stricto) e a caatinga das áreas sobre as bacias sedimentares (caatinga do sedimentar, também chamadas na literatura de caatingas de areia ou carrasco). O que Figueiredo (1997) chamou de "caatinga” (dividida em arbórea, arbustiva densa e arbustiva aberta) em seu sistema de classificação, são as caatingas do cristalino. Esse tipo vegetacional é o mais comum no estado do Ceará (Fig. 3), ocupando a maior parte de seu território.

Tipicamente, a caatinga do cristalino ocorre em solos rasos e pedregosos, com média a boa fertilidade que, entretanto, não têm como manter água edáfica após as chuvas, devido à sua pouca profundidade. Quanto à fisionomia, a caatinga do cristalino pode apresentar porte desde arbóreo até arbustivo denso ou arbustivo aberto (Veloso et al. 1991; Figueiredo 1997). Uma característica marcante da caatinga do cristalino é que plantas herbáceas representam uma porcentagem alta de espécies nas comunidades vegetais (Moro et al. 2014a). Na caatinga do cristalino, as plantas anuais (terófitas) são a forma de vida mais representativa na comunidade (Moro 2013). Árvores e arbustos (fanerófitos), entretanto, também são um componente fundamental. Isso permite definir estruturalmente a caatinga do cristalino como uma formação dominada por micro e nanofanerófitos (árvores e arbustos) no componente lenhoso, em geral decíduos e espinhosos, somados a um estrato herbáceo anual muito rico em espécies. Após a época de chuvas, as plantas lenhosas perdem suas folhas para suportar a seca, enquanto as terófitas morrem, permanecendo no solo apenas na forma de semente até que a próxima estação chuvosa chegue.
Figueiredo (1997) propôs a divisão da caatinga do cristalino do Ceará em três unidades fitoecológicas: 1. Floresta Caducifólia Espinhosa (Caatinga Arbórea); 2. Caatinga Arbustiva Densa; 3. Caatinga Arbustiva Aberta. Tal proposta se baseia no porte da vegetação, mas traz consigo algumas dificuldades. Temos observado em campo que áreas mapeadas em Figueiredo (1997) como caatinga arbustiva tem porte arbóreo e outras áreas mapeadas como caatinga arbórea tem porte arbustivo. Por outro lado, se considerarmos as áreas de caatinga da depressão sertaneja como uma única unidade fitoecológica, a caatinga do cristalino, teremos uma unidade mais coesa, com uma flora característica, condicionantes geológicos e ecológicos próprios e mais facilidade de mapeamento. Ademais, o porte da caatinga em uma área pode estar muito mais ligado ao histórico de impactos antrópicos do que a fatores ecológicos. Do ponto de vista de um sistema fitogeográfico, consideramos que a caatinga que cresce sobre a depressão sertaneja deve ser considerada como uma única fitounidade: caatinga do cristalino, a qual poderá ser descrita em estudos na escala local como de porte arbóreo, arbustivo denso ou arbustivo aberto. Quais seriam os vínculos florísticos entre a caatinga do cristalino e a mata seca do cristalino no Ceará é um ponto interessante a ser analisado. A publicação de mais estudos florísticos e fitossociológicos, com maior esforço amostral, é a chave para responder futuramente esta questão.

Embora a caatinga do cristalino seja o tipo de vegetação mais comum no estado, ela foi curiosamente ignorada pela maioria dos estudos florísticos publicados para o Ceará. Ambientes de ocorrência mais restrita, como as formações costeiras e carrasco (caatingas do sedimentar), e ambientes de exceção, como encraves de cerrado e matas úmidas, dispõem de mais proteção legal (Menezes et al. 2010), de mais coletas botânicas (Freitas \& Matias 2010) e de mais dados florísticos do que a caatinga do cristalino. Alguns trabalhos importantes nessa formação estão publicados em Costa et al. (2007), Araújo et al. (2011) e Costa \& Araújo (2012).

A caatinga do cristalino do Ceará está ameaçada especialmente pelo desmatamento e pastoreio excessivo para agricultura e pecuária, retirada de lenha, produção de carvão, bem como pelo processo de desertificação, em que a degradação excessiva do ambiente faz com que haja perda de solos e a vegetação não consiga se recuperar. 
Espécies características: Anadenanthera colubrina, Cereus jamacaru, Combretum leprosum, Commiphora leptophloeos, Cordia oncocalyx, Croton blanchetianus, Handroanthus impetiginosus, Libidibia ferrea, Luetzelburgia auriculata, Mimosa caesalpiniifolia, Mimosa tenuiflora, Piptadenia stipulacea, Poincianella gardneriana.

\section{Maciços Residuais Cristalinos: Mata Úmida do Cristalino e Mata Seca do Cristalino; e} 5. Superfícies sedimentares (Serra da Ibiapaba, Chapada do Araripe): Mata Úmida do Sedimentar, Mata Seca do Sedimentar, Caatinga do Sedimentar, Cerrado e Cerradão

Bordejando quase todo o limite ocidental do estado por cerca de $380 \mathrm{~km}$, a Serra da Ibiapaba caracteriza-se pela vertente íngreme na face voltada para o Ceará, a leste (front e topo), que apresenta as maiores altitudes (entre 800-900 m), e um suave caimento na direção do Piauí, o que caracteriza o relevo denominado cuesta, com o reverso da cuesta a oeste. A Serra da Ibiapaba é, na verdade, a borda da bacia sedimentar do Parnaíba (no Piauí e Maranhão), que foi elevada em função de processos morfoestruturais. Embora o substrato geológico seja o mesmo (Grupo Serra Grande), a diferenciação topográfica entre topo e reverso proporciona condições de umidade e precipitação diferenciadas entre os setores, com o topo recebendo mais pluviosidade que o reverso. Nos setores mais elevados há solos profundos (latossolos, sobretudo) e vegetação de porte arbóreo: a mata seca do sedimentar. Já no reverso da Ibiapaba ocorrem especialmente neossolos quartzarênicos, caracterizados por seu pouco desenvolvimento e seu caráter predominantemente arenoso e de baixa retenção de água para as plantas, com vegetação de caatinga do sedimentar (chamada regionalmente de carrasco).

Por sua vez, a Chapada do Araripe se localiza no extremo sul do Ceará e constitui-se em um relevo tabular de origem sedimentar, à semelhança da Serra da Ibiapaba, com comprimento de leste para oeste na ordem de $180 \mathrm{~km}$, com altitudes oscilando entre 800 e $900 \mathrm{~m}$, modeladas sobre litologias da Bacia do Araripe, de idade Cretácea. Assim como na cuesta da Ibiapaba, as características climáticas locais, sobretudo com maior precipitação média anual, permitiram significativos processos de pedogênese e o desenvolvimento de solos profundos, os latossolos vermelho-amarelos.
Diferentemente da Ibiapaba e do Araripe, que estão situadas em terrenos sedimentares, os Maciços Residuais localizam-se em substrato cristalino e ocupam diversos setores do território cearense, dispersos na depressão sertaneja (Fig. 2). Constituídos pelas rochas mais resistentes do embasamento cristalino, os maciços apresentam tamanhos diferentes e altitudes variadas, entre 450 a 700 e 700 a 900 metros e, por vezes, acima disso. Os maciços maiores apresentam condições morfométricas (vertentes menos íngremes, presença de platôs, etc.) para o desenvolvimento pedológico (argissolos vermelho-amarelos, principalmente) e, por conseguinte, melhores condições para o estabelecimento de cobertura vegetal. Os maciços de menor porte e que apresentam vertentes mais íngremes, por outro lado, são recobertos pelos neossolos litólicos.

Figueiredo (1997) considerou em seu sistema as categorias floresta subcaducifólia tropical pluvial (mata seca) e floresta subperenifólia tropical plúvio-nebular (mata úmida) como duas unidades fitoecológicas sem subdivisões, independente destas estarem localizadas sobre superfícies cristalinas ou sedimentares. Entretanto, embora as matas secas e as matas úmidas do cristalino tenham semelhança fisionômica com as matas secas e matas úmidas do sedimentar, respectivamente, a flora presente em áreas cristalinas e sedimentares é bastante diferenciada (ver seção de "comparações biogeográficas" adiante), de modo que consideramos que as matas úmidas do cristalino, matas úmidas do sedimentar, matas secas do cristalino e matas secas do sedimentar devem ser tratadas como unidades fitoecológicas distintas.

\section{- Mata Úmida do Cristalino e Mata Úmida do Sedimentar}

As matas úmidas do cristalino ocorrem no barlavento dos maciços residuais (serras) mais altos do Ceará. São ambientes de exceção na paisagem predominantemente semiárida do estado. Chamados de "brejos de altitude" na literatura botânica regional, as matas úmidas ocorrem no Ceará porque as serras mais altas barram o vento que vem do mar e forçam as massas de ar a subir. Com isso, essas massas de ar se resfriam e sua umidade se condensa, fazendo com que a face da serra voltada para o mar (barlavento) receba uma quantidade de chuvas bem superior a que precipita na caatinga ao redor. Esses brejos abrigam uma 
vegetação bastante diferenciada, com árvores muito maiores que as da caatinga típica e muitas espécies de epífitas, samambaias e briófitas. As matas úmidas (e subúmidas) do Ceará ocorrem em várias serras dispersas pelo estado, sendo as mais marcantes as serras cristalinas de Baturité, Maranguape, Aratanha, Uruburetama e Meruoca. Mas matas úmidas e subúmidas também ocorrem nos relevos sedimentares da Ibiapaba (por exemplo, em Ubajara) e do Araripe. O estudo mais aprofundado já realizado sobre a biota das matas úmidas cearenses foi direcionado à serra de Baturité (Oliveira \& Araújo 2007), mas definitivamente falta uma síntese biogeográfica da flora do conjunto das serras cearenses.

É possível que áreas como Baturité e Maranguape possuam uma influência mais forte da Mata Atlântica na sua biota, enquanto Ubajara, na Ibiapaba (a mata úmida mais a oeste do Ceará e que cresce em terrenos sedimentares) tenha uma influência amazônica mais forte. Algumas espécies da flora Amazônica co-ocorrem na serra da Ibiapaba como Catasetum planiceps e Buchenavia grandis, além de elementos faunísticos, como o caranguejo amazônico Fredius reflexifrons (Magalhães et al. 2005).

É possível que serras cristalinas muito interiores, como a serra do Pereiro ou a serra das Matas (Fig. 2), tenham tanto maior influência da flora atlântica (como em Baturité) ou que, por receberem bem menos chuvas que as serras próximas do mar, sejam constituídas por caatingas e matas secas do cristalino.

Um estudo florístico extenso publicado para a mata úmida do cristalino em Baturité está disponível em Oliveira \& Araújo (2007), enquanto que um levantamento florístico da mata úmida do sedimentar no Araripe está disponível em Ribeiro-Silva et al. (2012). Estudos florísticos e comparações biogeográficas em outras matas úmidas e subúmidas (Maranguape, Meruoca, Ubajara) são altamente desejáveis.

As matas úmidas estão bastante ameaçadas pelo desmatamento para produção agrícola e expansão urbana. Os "brejos" foram tradicionalmente reconhecidos como ambientes de maior vocação agrícola que o semiárido circundante e foram desmatados e explorados em ciclos agrícolas de produção de café, cana e banana (Macêdo 2013; Oliveira \& Araújo 2007), o que resultou em graves impactos na qualidade dos ecossistemas originais e em processos de erosão graves, com deslizamentos de terra e perda de solos. Ainda hoje as serras úmidas são utilizadas para produção de banana, cana e outros produtos agrícolas, mas recentemente a expansão imobiliária e o turismo resultaram em novas ameaças. Tanto pela expansão urbana de cidades localizadas nas regiões com matas úmidas (e.g. Guaramiranga) quanto pela aquisição de "sítios de veraneio" (que acabam sendo desmatados para instalar equipamentos humanos), a preservação desse conjunto vegetacional está ameaçada.

Algumas espécies só ocorrem nas matas úmidas do cristalino como Abarema jupunba e Manilkara rufula, enquanto outras só aparecem nas matas úmidas do sedimentar como Cordia bicolor e Centrolobium microchaete.

Espécies características: Abarema jupunba, Apeiba tibourbou, Ateleia guaraya, Centrolobium microchaete, Clusia nemorosa, Cordia bicolor, Cordia toqueve, Garcinia gardneriana, Guarea guidonia, Handroanthus serratifolius, Jacaratia spinosa, Manilkara rufula, Stryphnodendron guianense, Thyrsodium spruceanum.

\section{- Mata Seca do Cristalino e Mata Seca do Sedimentar}

Enquanto uma maior quantidade de chuvas nas partes altas do barlavento das serras permite a ocorrência de matas úmidas, o sotavento das mesmas serras e as cotas altitudinais mais baixas recebem uma quantidade menor de chuvas. São nessas áreas e nas serras mais afastadas do oceano que ocorrem as matas secas (Fig. 2; Fig. 3). Nos maciços cristalinos, as matas secas se diferenciam das caatingas do cristalino pelo porte maior das árvores, mas faltam estudos biogeográficos que mostrem a natureza florística dessas matas. É possível que sejam tanto uma forma de maior porte da caatinga do cristalino quanto uma formação floristicamente intermediária entre caatinga do cristalino e as matas úmidas ou, ainda, que sejam realmente um tipo de vegetação floristicamente bem definido.

Em relação às matas secas das áreas sedimentares, como as que ocorrem na Ibiapaba (Araújo et al. 2011), estas parecem ser, floristicamente, apenas um subtipo fisionômico de caatinga do sedimentar, pois sua flora é bastante relacionada à flora de outras áreas de caatinga do sedimentar do Nordeste (ver Moro 2013). Um levantamento florístico da mata seca de Baturité (cristalino) está disponível em Oliveira \& 
Araújo (2007) e sobre as matas secas da Ibiapaba (sedimentar) há dados disponíveis em Araújo et al. (2011) e Lima et al. (2009, 2011). Levantamentos em outras matas secas do Ceará são altamente desejáveis.

As matas secas são ameaçadas especialmente pelo sistema tradicional de corte e queima para agricultura. Uma vez esgotado o solo, o agricultor passa para outra área, que também é cortada e queimada. Depois de abandonada, eventualmente a mesma área é cortada e queimada novamente, prejudicando a recuperação da vegetação. A produção de granito ornamental ou brita para o setor de construção é outra ameaça, uma vez que morros inteiros (onde as matas secas ocorrem) são implodidos para retirada de granito.

Espécies características: Anadenanthera colubrina var. cebil, Aspidosperma multiflorum, Aspidosperma ulei, Brosimum gaudichaudii, Capparidastrum frondosum, Ceiba glaziovii, Chloroleucon dumosum, Combretum duarteanum, Cordia glabrata, Cordia trichotoma, Hymenaea courbaril, Machaerium acutifolium, Pterocarpus zehntneri, Spondias mombin, Zeyheria tuberculosa. Algumas espécies só ocorrem nas matas secas do cristalino como Cordia glabrata e Capparidastrum frondosum, enquanto outras só ocorrem nas matas secas do sedimentar, tais como Pterocarpus zehntneri e Zeyheria tuberculosa.

\section{- Caatinga do Sedimentar}

A caatinga do sedimentar, regionalmente chamada de carrasco, é uma vegetação decídua e não espinhosa que ocorre nas bacias sedimentares do Nordeste. Inicialmente se postulou que o carrasco seria um tipo diferenciado de vegetação do semiárido brasileiro, devido à sua fisionomia particular, dominada por arbustos, arvoretas e muitas lianas. Já em locais mais propícios, a vegetação de áreas sedimentares pode apresentar porte florestal, sendo chamada de mata seca do sedimentar (Araújo et al. 2011). Análises biogeográficas mostraram que as caatingas do sedimentar e as matas secas do sedimentar são floristicamente semelhantes entre as grandes bacias sedimentares do Nordeste (Queiroz 2006; Cardoso \& Queiroz 2007; Moro 2013; Gomes et al. 2006).

Embora essas áreas sedimentares sejam separadas geograficamente (ver Moro 2013 e Moro et al. 2014a), sua flora é mais similar entre áreas disjuntas e geograficamente distantes do que em relação a áreas próximas sobre ambiente cristalino. Com base nesses dados, Queiroz (2006, 2009) e Cardoso \& Queiroz (2007) consideraram que haveria pelo menos dois tipos distintos de caatinga no semiárido brasileiro: um sobre os ambientes cristalinos e outro sobre os ambientes sedimentares, sendo o carrasco floristicamente um tipo de caatinga do sedimentar.

Queiroz (2006, 2009) chamou atenção para o fato de que dentre as leguminosas (a família mais rica no semiárido brasileiro) a maioria das espécies endêmicas se localiza justamente nas áreas sedimentares e esse ambiente também apareceu como o mais rico em espécies no semiárido (Moro et al. 2014a).

Uma diferença estrutural marcante entre as caatingas do sedimentar e do cristalino é que nas áreas sedimentares a proporção de espécies herbáceas na comunidade é bem menor que nas áreas cristalinas (Moro 2013). Uma síntese recente demonstrou que, enquanto nas áreas cristalinas os terófitos são a forma de vida predominante, nas áreas sedimentares os fanerófitos são a forma de vida principal, embora também com a presença de terófitos (Moro 2013; Moro et al. 2014a).

As caatingas do sedimentar são um dos tipos de vegetação melhor caracterizados do semiárido brasileiro, com um número razoável de bons estudos publicados sobre a sua flora (ver compilação dos estudos disponíveis em Moro et al. 2015). Levantamentos florísticos e fitossociológicos para essa formação no Ceará estão disponíveis em Araújo \& Martins (1999), Araújo et al. (1998a, 1998b, 1999, 2011); Lima et al. (2009, 2011); Vasconcelos et al. (2010) e Ribeiro-Silva et al. (2012), e em uma região de transição sedimentar/cristalino em Lemos \& Meguro (2010).

As caatingas do sedimentar (carrasco) sofrem pressão da agricultura tradicional no Ceará, mas no estado do Piauí a implantação de grandes monoculturas mecanizadas (como as que resultaram na devastação do cerrado em poucas décadas) está em expansão e pode eliminar áreas consideráveis dessa vegetação em pouco tempo.

Espécies características: Dalbergia decipularis, Eugenia flavescens, Handroanthus chrysotrichus, Hymenaea velutina, Lindackeria ovata, Mimosa acutistipula, Mimosa verrucosa, Pityrocarpa moniliformis, Senegalia langsdorffii, Solanum crinitum, Swartzia psilonema, Zanthoxylum stelligerum. 
- Cerrado e cerradão (nas chapadas interiores e nos tabuleiros da região costeira)

O Domínio Fitogeográfico do Cerrado congrega um conjunto diverso de fitofisionomias características do Brasil central: campo limpo, campo sujo, cerrado sensu stricto, cerradão, florestas de galeria e outros (Ribeiro \& Walter 2008; Coutinho 2002). É considerado um dos hotspots de biodiversidade do planeta, ou seja, é extremamente diverso e altamente ameaçado (Myers et al. 2000). Dentre as vegetações que ocorrem no Domínio Fitogeográfico do Cerrado, o cerrado sensu stricto (chamado daqui em diante apenas de cerrado) e o cerradão se estendem até o Ceará (Fig. 3).

O cerrado é uma vegetação savânica, onde há dois componentes fisionômicos principais: 0 lenhoso, composto por árvores e arbustos, em geral de pequeno a médio porte, retorcidos e ramificados, e o herbáceo, formado por um conjunto diverso de espécies pertencentes a várias famílias como Poaceae, Cyperaceae, Velloziaceae, Malvaceae, dentre outras (Batalha \& Martins 2002; Ribeiro \& Walter 2008; Coutinho 2002). O componente herbáceo, no cerrado, forma uma camada contínua de revestimento perene do solo, recobrindo os espaços entre as árvores e arbustos esparsos (Eiten 1972; Coutinho 2002). Tanto a vegetação de cerrado quanto de caatinga do cristalino têm um estrato herbáceo rico em espécies, mas, diferentemente da caatinga do cristalino, a cobertura herbácea do cerrado é perene, enquanto na caatinga a maioria das espécies é terofítica, anual, e morre ao fim da estação chuvosa (Moro 2013; Loefgren 1923).

O cerradão é a fisionomia florestal do cerrado sensu lato. Tipicamente, em locais onde incêndios são menos frequentes, ou em locais onde por ação antrópica os incêndios são combatidos e controlados (como nas unidades de conservação), o componente lenhoso vai se tornando cada vez mais denso. Assim, com o tempo, onde antes havia uma fisionomia campestre passa a haver uma savana e onde havia savana passa a ocorrer o cerradão (Coutinho 2002; Ribeiro \& Walter 2008; Pinheiro \& Durigan 2009).

Aárea de ocorrência contínua do Domínio do Cerrado se localiza no Brasil Central, estendendose também para o Sudeste, Centro-Oeste e parte do Nordeste. No Nordeste, o cerrado é amplamente distribuído no oeste da Bahia e em boa parte do Piauí e Maranhão (Castro \& Martins 1999; IBGE 2004; Ratter et al. 2003). Além das áreas contínuas, manchas disjuntas de cerrado ocorrem em meio à Amazônia e no nordeste do Brasil (Ratter et al. 2003). As manchas disjuntas de cerrado do Ceará (Fig. 3) estão ligadas especialmente aos tabuleiros costeiros (e.g. Moro et al. 2011), à Chapada do Araripe (Costa et al. 2004; Costa \& Araújo 2007; Ribeiro-Silva et al. 2012), à Serra da Ibiapaba e a relevos residuais sedimentares menores, localizados no sul do estado (Figueiredo \& Fernandes 1987).

Próximo ao Sertão do Salgado, em municípios como Lavras da Mangabeira (o nome do município cearense faz referência à mangabeira - Hancornia speciosa - uma espécie de cerrado), há manchas de cerrado reportadas, ligadas justamente aos relevos sedimentares residuais da região (Figueiredo \& Fernandes 1987). Levantamentos florísticos e fitossociológicos no cerrado e cerradão foram publicados por Figueiredo \& Fernandes (1987), Costa et al. (2004), Costa \& Araújo (2007), Moro et al. (2011) e Ribeiro-Silva et al. (2012).

As espécies lenhosas do cerradão são em grande medida semelhantes àquelas do cerrado, mas no cerradão o componente herbáceosubarbustivo é reduzido. Isso levanta a questão sobre como o fogo deve ser manejado em políticas de conservação. A eliminação completa dos incêndios leva à substituição do cerrado pelo cerradão, e o aumento da frequência dos incêndios leva à substituição do cerrado pelo campo sujo ou até campo limpo. Ainda é controverso o modo como o ser humano deve manejar o regime de fogo em unidades de conservação do cerrado, pois, caso os incêndios sejam rigorosamente impedidos, a vegetação torna-se progressivamente mais densa, excluindo as espécies que dependem de ambientes abertos (Pinheiro \& Durigan 2009). Isso tem sido observado na Floresta Nacional do Araripe, onde o controle de incêndios tem reduzido as populações de janaguba (Himatanthus drasticus) (C. Baldauf, comunicação pessoal). O mesmo efeito foi observado no litoral do Ceará, onde áreas suscetíveis ao fogo têm populações densas de janaguba (Moro et al. 2011) enquanto em áreas sem fogo as janagubas são raras (Castro et al. 2012).

Espécies características: Agonandra brasiliensis, Bowdichia virgilioides, Callisthene fasciculata, Curatella americana, Hancornia speciosa, Himatanthus drasticus, Hirtella ciliata, Hymenaea stigonocarpa, Leptolobium dasycarpum, Mouriri pusa, Ouratea hexasperma, Psidium myrsinites, Salvertia convallariodora, Simarouba versicolor, Vatairea macrocarpa. 


\section{Ambientes especiais}

As unidades fitoecológicas propostas por Figueiredo (1997) se referem aos ambientes reconhecíveis em mapeamentos de média escala (escala estadual), mas alguns ambientes do semiárido não aparecem naquela proposta porque só são mapeáveis em grande escala ${ }^{1}$. Dentre esses ambientes estão os inselbergs e os pequenos corpos aquáticos temporários do Ceará. Mesmo com pequena extensão, são ambientes de grande importância ecológica pois abrigam uma biota particular, adaptada, respectivamente, a ambientes rochosos (Bromeliáceas, Cactáceas, Briófitas e outras plantas que conseguem viver em locais com solo praticamente ausente) e aquáticos.

\section{- Vegetação Rupícola: inselbergs e lajedos}

A vegetação rupícola ocorre em ambientes rochosos, onde os solos são pouco desenvolvidos (neossolos litólicos), seja nos lajedos, seja nos inselbergs. Inselberg é um termo alemão (Insel = ilha; Berg = montanha) que poderia ser traduzido como "ilha-montanha" ou mais claramente como “uma montanha que é uma ilha”, e se refere aos grandes maciços rochosos que se destacam na paisagem relativamente plana da Depressão Sertaneja. Nos inselbergs, a rocha se apresenta geralmente nua e os solos são ausentes, pouco desenvolvidos (neossolos litólicos) ou são restritos a rachaduras e concavidades da rocha. A rigor, inselbergs não são um tipo específico de vegetação, mas sim uma feição geomorfológica que ocorre quando rochas mais resistentes à erosão resistem na paisagem como blocos rochosos expostos. Por extensão, atribui-se o nome inselberg aos ambientes rupícolas dos inselbergs e à vegetação que ocorre nesses ambientes.

Ambientes rochosos também ocorrem nos chamados lajedos, que por sua vez, são terrenos planos, e que não se destacam na paisagem como os inselbergs, mas que possuem neossolos litólicos com biota semelhante aos dos inselbergs do cristalino. Além dos ambientes rochosos do cristalino (inselbergs formados por rochas cristalinas e metamórficas), ambientes rochosos também ocorrem em áreas sedimentares, onde a vegetação cresce sobre solos pouco desenvolvidos ou agarrada à rocha nua.

Inselbergs e lajedos são ambientes estressantes para as plantas, com forte restrição hídrica durante a estação seca, já que a ausência de solos não propicia o acúmulo de água (Porembski 2007; Biedinger et al. 2000). Apesar disso, os ambientes rupícolas do semiárido possuem número elevado de espécies (Moro et al. 2014a).

De modo geral, os inselbergs podem ser considerados ambientes pouco estudados no Ceará: o único estudo sobre vegetação rupícola foi publicado para um inselberg de Quixadá (Araújo et al. 2008), e nenhum estudo florístico sobre os ambientes rupícolas de áreas sedimentares foi publicado até o momento. Novos estudos em áreas rupícolas do cristalino e do sedimentar são altamente desejáveis.

A flora rupícola é ameaçada principalmente pela mineração, que destrói inselbergs para produção de brita ou rochas ornamentais (especialmente granitos, no Ceará) para a construção civil. Além disso, o pastoreio, especialmente de caprinos, é uma fonte extra de impactos para a vegetação. A coleta de plantas para venda como plantas ornamentais também é um impacto potencial.

Espécies características: Aosa rupestris, Apodanthera congestiflora, Catasetum planiceps, Chresta pacourinoides, Cordia glabrata, Crotalaria holosericea, Encholirium spectabile, Pilosocereus gounellei, Mandevilla tenuifolia, Manihot carthaginensis subsp glaziovii, Marsdenia megalantha, Matelea endressiae, Pilosocereus chrysostele.

• Vegetação Aquática e Paludosa: rios
temporários, lagoas temporárias, lagoas
perenes e reservatórios artificiais
O Ceará está majoritariamente sob a
influência do clima semiárido. Com isso, a maioria
dos corpos hídricos são temporários. Contudo, com
a construção de barragens artificiais, vários dos
rios sazonais foram artificialmente perenizados.

\footnotetext{
${ }^{1}$ Cartograficamente, a escala grande é aquela que aborda uma área pequena com muitos detalhes (por exemplo escala 1:1.000), ou seja, é aquela de abrangência local. Já a escala pequena é aquela em que uma área grande é representada com poucos detalhes (por exemplo, 1:1.000.000), ou seja, de abrangência regional, nacional ou continental. Um mapeamento na escala do Brasil possui pequena escala e outro na escala dos inselbergs de Quixadá possui grande escala. No caso, inselbergs e pequenas lagoas e rios temporários só aparecem em mapeamentos de grande escala, aqueles em escala local, com grande grau de detalhamento.
} 
Poucos sistemas hídricos do Ceará, a exemplo de algumas grandes lagunas costeiras, como o Lagamar do Cauípe, são naturalmente perenes.

O ambiente aquático é radicalmente diferente do terrestre em sua ecologia. Dentro da água as plantas não precisam de cutículas espessas e mecanismos eficientes para evitar a desidratação; o $\mathrm{CO}_{2}$ para a fotossíntese está dissolvido; e as plantas se utilizam de aerênquimas para que as folhas tenham diferentes níveis de flutuabilidade, a depender se a espécie é uma planta submersa, emersa ou flutuante. Parte da biota vegetal dos corpos hídricos é composta por plantas exclusivamente aquáticas, que dependem desse ambiente para crescer, e parte são espécies anfíbias, que podem crescer tanto em ambientes terrestres quanto suportar o encharcamento do solo em parte do ano. É comum que a vegetação anfíbia constitua campos brejosos, ricos em Poaceae e Cyperaceae, além da presença de plantas exclusivamente aquáticas em locais inundados por mais tempo, como as das

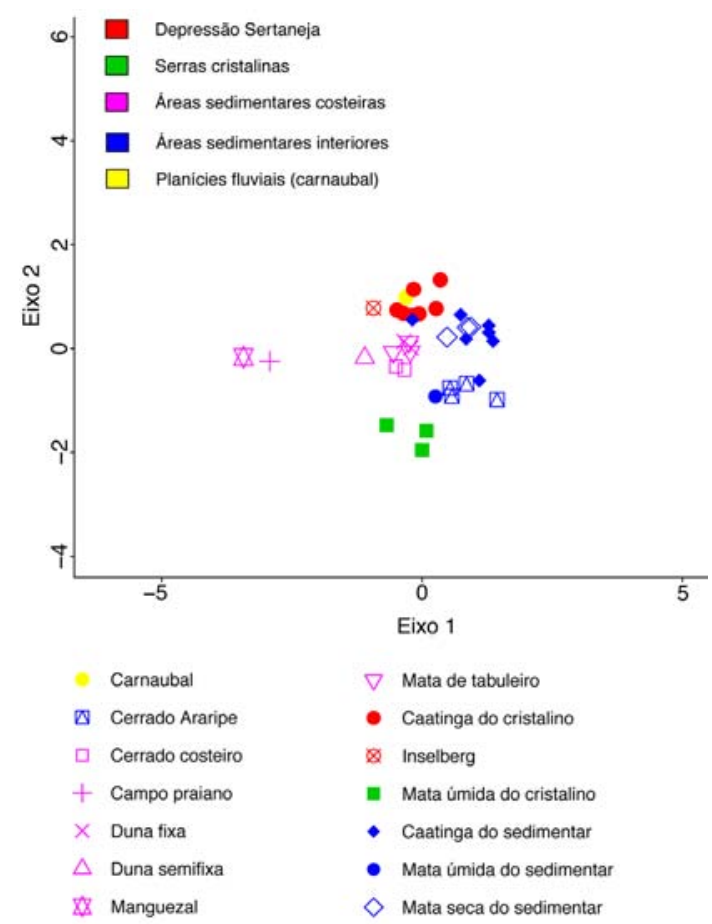

Figura 4 - Gráfico de ordenação NMS (distância de Bray-Curtis) mostrando as afinidades de espécies entre a flora geral (incluindo plantas lenhosas e herbáceas) das diferentes vegetações do estado do Ceará. Stress final para a solução bidimensional: 0.1456576 .

Figure 4 - NMS Ordination graph (Bray-Curtis distance used) showing the floristic resemblance among the vegetation types in Ceará state. Final stress for the bidimentional solution: 0.1456576. famílias Alismataceae e Nymphaeaceae. Por ser um ecossistema completamente diferente do terrestre, ambientes aquáticos possuem uma flora bastante peculiar e muito diferente floristicamente de todas as outras comunidades vegetais do semiárido (Moro et al. 2014a).

Ao contrário do que se poderia pensar à primeira vista, o semiárido brasileiro não é pobre em espécies aquáticas e anfíbias. Análogo ao que ocorre no Pantanal, o Domínio da Caatinga está submetido a um ciclo de alternância entre estações secas e chuvosas. Com isso, é possível encontrar no Ceará uma flora especializada nos corpos hídricos, a exemplo das famílias Alismataceae e Nymphaeaceae (Sousa \& Matias 2013; Matias \& Sousa 2011). Levantamentos florísticos e fitossociológicos nos ambientes aquáticos do Ceará estão disponíveis em Matias et al. (2003), Castro et al. (2012), Tabosa et al. (2012) e Moro et al. (2014b).

Os corpos hídricos no Ceará sofrem ameaças pela poluição derivada da indústria e da falta de saneamento básico; pelo assoreamento generalizado, resultante do desmatamento das vegetações ripárias que protegem os rios; pela construção excessiva de açudes e barragens, os quais alteram a ecologia dos rios; e pelo aterramento para expansão urbana.

Embora seja óbvia a necessidade de cuidar da qualidade dos recursos hídricos em uma região semiárida, rios e lagoas tiveram e ainda têm sua vegetação ripária erradicada por particulares e pelo poder público. Dentre os mais ameaçados estão os corpos hídricos localizados em áreas urbanas. Mesmo protegidos por lei, eles são rotineiramente utilizados para depósito de lixo, aterrados ou canalizados por particulares e pelo poder público. A incapacidade (ou falta de desejo) humana para perceber e se inserir de modo adequado em processos ecológicos, como nos ritmos de cheia e seca dos corpos hídricos, resultou em obras indiscriminadas de canalização e aterramento de rios e lagoas (Maia Neto 2013). Mesmo hoje, com uma compreensão dos processos ecológicos e da importância social da água, e apesar da proteção jurídica, os corpos hídricos são comumente canalizados e aterrados, atendendo a interesses privados e quase sempre com suporte do poder público, mesmo que contra a lei. Como destaca Maia Neto (2013), as ações humanas em relação aos ecossistemas aquáticos do Ceará tem sido historicamente a de "controlar o caminho das águas”, mas nunca a de respeitar esse caminho.

Também destacamos as ameaças resultantes da introdução de peixes exóticos em projetos de 
açudagem, sem que haja nenhuma preocupação com os impactos que a fauna invasora trará às espécies nativas. Embora o Brasil seja signatário da Convenção sobre Diversidade Biológica de 1992, que prevê o controle de espécies invasoras, o poder público tem dado suporte à disseminação de organismos invasores nos mais variados ecossistemas do Ceará (incluindo os aquáticos).

Espécies características: Acrostichum aureum, Alternanthera brasiliana, Alternanthera tenella, Echinodorus subalatus, Eichhornia azurea, Eichhornia crassipes, Eleocharis interstincta, Eleocharis mutata, Hydrocleys nymphoides, Hydrocotyle leucocephala, Ipomoea carnea

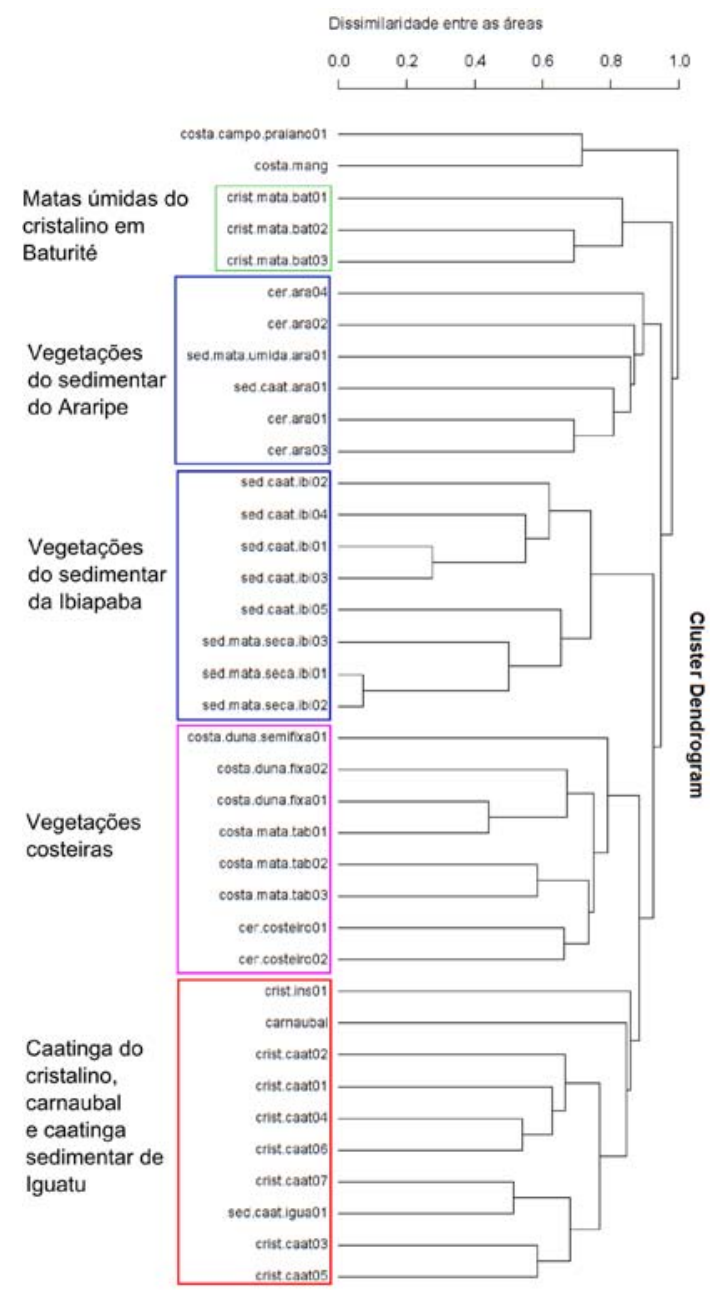

Figura 5 - Gráfico UPGMA (distância de Bray-Curtis) mostrando as afinidades de espécies entre a flora das diferentes vegetações do estado do Ceará.

Figure 5 - UPGMA graph (Bray-Curtis distance used) showing the floristic resemblance among the vegetation types in Ceará state. subsp. fistulosa, Justicia laevilinguis, Ludwigia octovalvis, Montrichardia linifera, Neptunia oleracea, Nymphaea lasiophylla, Nymphoides indica, Pistia stratiotes, Salvinia auriculata.

\section{Comparações biogeográficas}

Afim de interpretar as diferenças e semelhanças florísticas entre as diferentes vegetações do Ceará, utilizamos análises multivariadas de agrupamento e ordenação usando dados de presença-ausência de espécies reportadas em levantamentos florísticos disponíveis para o estado (Apêndice 2).

De todas as vegetações do estado, o manguezal e o campo praiano (equivalente ao que se chama de vegetação de restinga em outros estados brasileiros) foram as vegetações mais diferentes floristicamente em nossas análises (Fig. 4; 5). Isso é reflexo do ambiente salino e altamente estressante a que as plantas dos manguezais e restingas estão expostas, ao qual poucas espécies conseguem se adaptar. Em seguida, temos o grupo formado por todos os outros levantamentos, o qual pode ser subdividido nos seguintes subgrupos:

Subgrupo 1 - levantamentos da mata úmida do cristalino (Serra de Baturité), que formou um grupo relativamente coeso (Fig. 5), embora levantamentos nas outras serras úmidas do cristalino do Ceará não estejam publicados para comparação.

Subgrupos 2 e 3 - vegetação das superfícies sedimentares interiores, as quais aparecem nas análises subdivididas entre os levantamentos na Chapada do Araripe e os na Cuesta da Serra da Ibiapaba (Fig. 4; 5). Moro (2013) mostrou que as matas secas da Ibiapaba eram similares floristicamente às caatingas do sedimentar (carrasco). Assim, quando Figueiredo (1997, ver também Fig. 3) se refere às matas secas, do ponto de vista florístico, parece ser mais apropriado considerar as matas secas presentes nas áreas sedimentares como uma unidade fitoecológica distinta das matas secas do cristalino, tal como aqui foi adotado. Quando consideramos a flora geral (i.e. tanto espécies lenhosas quanto herbáceas), nossos dados mostram que as matas secas do sedimentar, o carrasco e o cerrado da Ibiapaba-Araripe formaram um grupo florístico (Fig. 4). Vale ressaltar que as floras lenhosas dos cerrados do Araripe e cerrados costeiros têm dominância de elementos dos cerrados do Brasil central, muito embora haja o ingresso na comunidade de espécies típicas da Caatinga (Moro et al. 2011). Essa formação pode, portanto, ser reconhecida pela fisionomia savânica 
e pela dominância, na comunidade lenhosa, de espécies típicas do domínio do Cerrado, mas em relação à flora geral, os cerrados costeiros se vinculam à flora da região costeira e os cerrados do Araripe à flora das bacias sedimentares interiores.

Subgrupo 4 - formado pelo conjunto de vegetações costeiras do estado, incluindo as matas de tabuleiro, cerrados costeiros, vegetação de dunas fixas e vegetação de dunas móveis e semifixas, mas excluindo o manguezal e o campo praiano. Embora as comunidades lenhosas do cerrado costeiro sejam dominadas por plantas do Domínio Fitogeográfico do Cerrado, elas também contam com elementos de outros domínios (Moro et al. 2011). Como o método adotado nas comparações levou em conta apenas presençaausência, e não abundância, os cerrados costeiros se aproximaram das matas de tabuleiro. Ademais, conforme destacado por Moro et al. (2011), a comunidade de plantas herbáceas dos cerrados costeiros conta com diversos elementos típicos da flora costeira brasileira, explicando a afinidade florística com as demais formações costeiras. Como um todo, a região costeira do Ceará, caracterizada pelo predomínio dos tabuleiros (Formação Barreiras) e dos campos de dunas, forma um grupo florístico diferenciado em relação à flora de outras regiões do estado, o que já havia sido ressaltado pelo naturalista Francisco Freire Alemão no século XIX. Conforme destacamos em outros trabalhos (Castro et al. 2012; Moro et al. 2011), a flora costeira do Ceará é uma mistura de elementos típicos de áreas costeiras do Brasil com elementos dos domínios do Cerrado, da Caatinga e até mesmo da Mata Atlântica.

Subgrupo 5 - formado pelas áreas de caatinga do cristalino, inselberg e o carnaubal (Fig. 4; Fig. 5). O inselberg analisado, localizado em meio ao semiárido, em Quixadá (Araújo et al. 2008), apresentou uma flora semelhante à das caatingas do cristalino, embora, dentro deste grupo, seja o mais diferente, provavelmente refletindo a presença de elementos típicos de áreas rupícolas. O carnaubal estudado, mesmo localizado na região costeira do estado, também se aproximou da flora da caatinga do cristalino (Fig. 4; 5), reforçando a ideia de Andrade-Lima (1981) de que os carnaubais seriam um dos subtipos de caatinga. Uma única área de caatinga do sedimentar se agrupou com as caatingas do cristalino. Essa área é localizada na Bacia Sedimentar de Iguatu (Lima et al. 2012), a qual é uma bacia sedimentar de pequena extensão quando comparada às bacias do Araripe e da Ibiapaba. O porquê dessa única área sedimentar ter se juntado à flora do cristalino ainda não é claro, mas podemos lançar três hipóteses. Uma é que a bacia, pelo seu pequeno tamanho, esteja sendo ocupada pela flora da caatinga do cristalino circundante. Outra é que o levantamento tenha sido feito em uma área ecotonal entre o sedimentar e o cristalino da bacia, daí a presença marcante de espécies da caatinga do cristalino. A terceira é que a bacia de Iguatu, assim como a do Apodi, tenha solos eutróficos, diferentes dos solos pobres em nutrientes do Araripe e da Ibiapaba e, devido a diferenças edáficas, essa área tenha uma flora diferente das outras áreas sedimentares do estado.

Esses resultados permitem uma interpretação das semelhanças florísticas entre as diferentes vegetações do estado. As afinidades florísticas, somadas às diferenças fisionômicas entre cada tipo vegetacional e às diferenças de geologia entre áreas, são a base para o reconhecimento das unidades fitoecológicas aqui adotadas, à partir de modificações do sistema de Figueiredo (1997).

\section{Conclusões}

Apresentamos aqui uma revisão geral sobre a fitogeografia do Ceará. Esse trabalho objetivou descrever uma a uma as principais vegetações do estado e especialmente mostrar a correlação que há entre as unidades morfoestruturais e a vegetação e flora cearenses, buscando assim uma síntese fitogeográfica para o estado. Usando análises multivariadas, verificamos que há uma relação considerável entre a vegetação e a flora e cada unidade geomorfológica. Esperamos que a descrição de cada vegetação e as explicações sobre os condicionantes que determinam a distribuição de cada uma amplie o entendimento de alunos e pesquisadores sobre a biogeografia do estado e estimule novas pesquisas sobre a biodiversidade cearense.

\section{Material suplementar}

Esse artigo conta com quatro apêndices e dois suplementos digitais: o apêndice 1 traz pranchas fotográficas com paisagens do Ceará; o apêndice 2 traz a lista de levantamentos florísticos utilizados nas comparações fitogeográficas; o apêndice 3 traz uma tabela mostrando a correspondência entre os termos utilizados neste trabalho e nos sistemas de Figueiredo (1997) e de Veloso et al. (1991); o apêndice 4 traz um organograma mostrando a relação entre os tipos vegetacionais 
e as unidades de relevo do Ceará; o suplemento digital 1 disponível em (<http://dx.doi.org/10.6084/ m9.figshare.1289920> traz um acervo fotográfico do Ceará com fotos representativas das vegetações e paisagens do estado; o suplemento digital 2 disponível em (<http://dx.doi.org/10.6084/ m9.figshare.1289930>) traz os mapas apresentados no artigo, um arquivo KML (Keyhole Markup Language) para visualizar as vegetações do Ceará no programa Google Earth (ou outro software SIG de preferência do usuário), um organograma mostrando a relação de cada tipo vegetacional com as unidades de relevo, uma tabela indicando algumas das espécies mais típicas para cada vegetação, a matriz de dados utilizada nas análises fitogeográficas e as referências bibliográficas dos trabalhos usados nas comparações biogeográficas.

\section{Agradecimentos}

M.F. Moro agradece à Fundação de Amparo à Pesquisa do Estado de São Paulo (processo Fapesp 2013/15280-9), a bolsa de pós-doutorado concedida. M.B. Macedo agradece ao Conselho Nacional de Desenvolvimento Científico e Tecnológico (processo CNPq 140085/2014-9), a bolsa de Doutorado concedida. Agradecemos ao amigo Marcelo de Oliveira Teles de Menezes por ceder fotos da caatinga para ilustrar este trabalho.

\section{Referências}

Andrade-Lima, D. 1981. The caatingas dominium. Revista Brasileira de Botânica 4: 149-153.

Arai, M. 2006. A grande elevação eustática do Mioceno e sua influência na origem do Grupo Barreiras. Revista do Instituto de Geociências - USP 6: 1-6.

Araújo, F.S.; Sampaio, E.V.D.S.B.; Figueiredo, M.A.; Rodal, M.J.N. \& Fernandes, A.G. 1998. Composição florística da vegetação de carrasco, Novo Oriente, CE. Revista Brasileira de Botânica 21: 105-116.

Araújo, F.S.; Costa, R.C.; Lima, J.R.; Vasconcelos, S.F.; Girão, L.C.; Souza Sobrinho, M.; Bruno, M.M.A. et al. 2011. Floristics and life-forms along a topographic gradient, central-western Ceará, Brazil. Rodriguésia 62: 341-366.

Araújo, F.S.; Sampaio, E.V.D.S.B.; Rodal, M.J.N. \& Figueiredo, M.A. 1998. Organização comunitária do componente lenhoso de três áreas de carrasco em Novo Oriente - CE. Revista Brasileira de Biologia 58: 85-95.

Araújo, F.S. de \& Martins, F.R. 1999. Fisionomia e organização da vegetaçao do carrasco no Planalto da Ibiapaba, estado do Ceará. Acta Botanica Brasilica 13: $1-13$.
Araújo, F.S.; Martins, F.R. \& Shepherd, G.J. 1999. Variações estruturais e florísticas do carrasco no planalto da Ibiapaba, estado do Ceará. Revista Brasileira de Biologia 59: 663-678.

Araújo, F.S.; Oliveira, R.F. \& Lima-Verde, L.W. 2008. Composição, espectro biológico e síndromes de dispersão da vegetação de um inselbergue no domínio da Caatinga, Ceará. Rodriguésia 59: 659-671.

Araújo, L.M. \& Moura, F.B.P. 2007. A expansão do turismo na zona costeira nordestina: crescimento econômico, degradação ambiental e erosão cultural. In: Coriolano, L.N. \& Vasconcelos, F.P. (eds.). O turismo e a relação sociedade-natureza: realidades, conflitos e resistências. Editora da Universidade Estadual do Ceará, Fortaleza. Pp. 94-114

Batalha, M.A. \& Martins, F.R. 2002. Life-form spectra of Brazilian cerrado sites. Flora 197: 452-460.

Bezerra, F.H.; Amaro, V.E.; Vita-Finzi, C. \& Saadi, A. 2001. Pliocene-Quaternary fault control of sedimentation and coastal plain morphology in NE Brazil. Journal of South American Earth Sciences 14: 61-75.

Biedinger, N.; Porembski, S. \& Barthlott, W. 2000. Vascular Plants on Inselbergs: Vegetative and Reproductive Strategies. In: Inselbergs: biotic diversity of isolated rock outcrops in tropical and temperate regions. Springer, Berlin. Pp. 117-142.

Braga, R. 1962. História da Comissão Científica de Exploração. Imprensa Universitária do Ceará, Fortaleza. 410p.

Brandão, R.L. 1995. Sistema de informações para Gestão e Administração Territorial da Região Metropolitana de Fortaleza - Projeto SINFOR: Diagnostico Geoambiental e os principais problemas de ocupação do meio físico da Região Metropolitana de Fortaleza. CPRM/SEMACE/SRH, Fortaleza. 105p.

Cardoso, D.B.O.S. \& Queiroz, L.P. 2007. Diversidade de Leguminosae nas Caatingas de Tucano, Bahia: implicações para a fitogeografia do semi-árido do Nordeste do Brasil. Rodriguésia 58: 379-391.

Castro, A.A.J.F. \& Martins, F.R. 1999. Cerrados do Brasil e do Nordeste: caracterização, área de ocupação, considerações sobre sua fitodiversidade. Pesquisa em Foco 7: 147-178.

Castro, A.S.F.; Moro, M.F. \& Menezes, M.O.T. de. 2012. O Complexo Vegetacional da Zona Litorânea no Ceará: Pecém, São Gonçalo do Amarante. Acta Botanica Brasilica 26: 108-124.

Claudino-Sales, V. 1993. Cenários litorâneos - Lagoa do Papicu: natureza e ambiente na cidade de Fortaleza, CE. Dissertação de Mestrado em Geografia. Universidade de São Paulo, São Paulo. 349p.

Claudino-Sales, V. 2005. Os litorais cearenses. In: Silva, J.B.; Dantas, E.W.C. \& Cavalcante, M.T. (eds.) Ceará: um novo olhar geográfico. Edições Demócrito Rocha, Fortaleza. 480p. 
Claudino-Sales, V.C. 2002. Les littoraux du Ceará. Evolution géomorphologique de la zone côtiére de l'Etat du Ceará, Brésil - du long terme au court terme. Tese de Doutorado. Université ParisSorbonne, Paris. 523p.

Costa, I.R. \& Araújo, F.S. 2007. Organização comunitária de um encrave de cerrado sensu stricto no bioma Caatinga, chapada do Araripe, Barbalha, Ceará. Acta Botanica Brasilica 21: 281-291.

Costa, I.R.; Araújo, F.S. \& Lima-Verde, L.W. 2004. Flora e aspectos auto-ecológicos de um encrave de cerrado na chapada do Araripe, Nordeste do Brasil. Acta Botanica Brasilica 18: 759-770.

Costa, R.C. \& Araújo, F.S. 2012. Physiognomy and structure of a caatinga with Cordia oncocalyx (Boraginaceae), a new type of community in Andrade-Lima's classification of caatingas. Rodriguésia 63: 269-276.

Costa, R.C.; Araújo, F.S. \& Lima-Verde, L.W. 2007. Flora and life-form spectrum in an area of deciduous thorn woodland (caatinga) in northeastern, Brazil. Journal of Arid Environments 68: 237-247.

Coutinho, L.M., 2002. O bioma do cerrado. In: Klein, A.L. (ed.). Eugen Warming e o cerrado brasileiro: um século depois. Editora UNESP, São Paulo. Pp. 77-91.

CPRM [Serviço Geológico do Brasil]. 2003. Atlas digital de Geologia e Recursos minerais do Ceará. Mapas na Escala 1:500.000, Cd Rom.

Eiten, G. 1972. The cerrado vegetation of Brazil. The Botanical Review 38: 201-341.

EMBRAPA [Empresa Brasileira de Pesquisa Agropecuária]. 2006. Sistema brasileiro de classificação de solos. EMBRAPA, Rio de Janeiro. 306p.

Feijó, J.S. 1818. Collecção descriptiva das plantas da Capitania do Seará [1818?] (transcrição do manuscrito não publicado). In: Pereira, M.R.M \& Santos, R.M.F. (eds.). João da Silva Feijó: um homem de ciência no antigo regime português (2012). Editora da Universidade Federal do Paraná, Curitiba. 1046p.

Figueiredo, M.A. 1997. A cobertura vegetal do Ceará (Unidades Fitoecológicas). In: Atlas do Ceará. Governo do Estado do Ceará; IPLANCE, Fortaleza. 65p.

Figueiredo, M.A. 1986. Vegetação. In: Atlas do Ceará. Superintendência do Desenvolvimento do Estado do Ceará-SUDEC, Fortaleza. 57p.

Figueiredo, M.A. \& Fernandes, A. 1987. Encraves de cerrado no interior do Ceará. Ciência Agronômica 18: $103-106$.

Fortaleza. 2003. Inventário ambiental de Fortaleza. Prefeitura Municipal de Fortaleza, Fortaleza. 430p.

Freitas, R.C.A. \& Matias, L.Q. 2010. Situação amostral e riqueza de espécies das Angiospermas do estado do
Ceará, Brasil. Acta Botanica Brasilica 24: 964-971.

Gomes, A.P.S.; Rodal, M.J.N. \& Melo, A.L. 2006. Florística e fitogeografia da vegetação arbustiva subcaducifólia da Chapada de São José, Buíque, PE, Brasil. Acta Botanica Brasilica 20: 37-48.

Huber, J. 1908. Plantas do Ceará: lista de plantas vasculares colhidas no Estado do Ceará (Brasil) nos mezes de setembro e outubro de 1897. Revista do Instituto do Ceará 22: 164-192.

IBGE [Instituto Brasileiro de Geografia e Estatística]. 2012. Manual técnico da vegetação brasileira. IBGE, Rio de Janeiro.

IBGE [Instituto Brasileiro de Geografia e Estatística]. 2004. Mapa de biomas do Brasil: primeira aproximação. IBGE, Rio de Janeiro.

IBGE [Instituto Brasileiro de Geografia e Estatística]. 2002. Mapa de clima do Brasil. IBGE, Rio de Janeiro.

IPLANCE [Fundação Instituto de Planejamento do Ceará], 1997. Atlas do Ceará. Governo do Estado do Ceará. IPLANCE, Fortaleza. 65p.

Legendre, P. \& Legendre, L. 2012. Numerical Ecology. Elsevier, Amsterdam. 990p.

Lemos, J.R. \& Meguro, M. 2010. Florística e fitogeografia da vegetação decidual da Estação Ecológica de Aiuaba, Ceará, Nordeste do Brasil. Revista Brasileira de Biociências 8: 34-43.

Libano, A.M. \& Felfili, J.M. 2006. Mudanças temporais na composição florística e na diversidade de um cerrado sensu stricto do Brasil Central em um período de 18 anos (1985-2003). Acta Botanica Brasilica 20: 927-936.

Lima, B.G.; Coelho, M.F.B. \& Oliveira, O.F. 2012. Caracterização florística de duas áreas de caatinga na região centro-sul do Ceará, Brasil. Bioscience Journal 28: 277-296.

Lima, J.R.; Sampaio, E.V.S.; Rodal, M.J.N. \& Araújo, F.S. 2009. Composição florística da floresta estacional decídua montana de Serra das Almas, CE, Brasil. Acta Botanica Brasilica 23: 756-763.

Lima, J.R.; Sampaio, E.V.S.B.; Rodal, M.J.N. \& Araújo, F.S. 2011. Physiognomy and structure of a seasonal deciduous forest on the semiarid Ibiapaba plateau, Ceará, Brazil. Rodriguésia 62: 379-389.

Lima, E.L.V. \& Meireles, A.J.A. 2006. Serviluz, embate entre questões sociais e ambientais. In: Silva, J.B.; Dantas, E.W.C.; Zanella, M.E.; Meireles, A.J.A. (eds.). Litoral e sertão: natureza e sociedade no nordeste brasileiro. Expressão Gráfica, Fortaleza. 408p.

Loefgren, A. 1923. Notas Botânicas (Ceará). Inspectoria de Obras Contra as Secas, Rio de Janeiro. XLII + 35p. + pranchas.

Macêdo, M.B. 2013. Diferentes nuanças de uma mesma cor: mudanças de significado da Serra de Maranguape (CE). In: Funes, E. et al. (eds.). 
Natureza e Cultura: capítulos de história social. Vol. 10. Expressão Gráfica, Fortaleza. Pp 131-145.

Magalhães, C.; Abrunhosa, F.A.; Pereira, M.D.O. \& Melo, M.A. 2005. New records of Fredius denticulatus (H. Milne-Edwards, 1853) and $F$. reflexifrons (Ortmann, 1897), and the eastern limits of the distribution of pseudothelphusid crabs (Crustacea: Decapoda) in Brazil. Acta Amazonica 35: 93-96.

Maia Neto, E.F. 2013. A teima das águas: chuvas, riachos e obras públicas em Fortaleza (1810-1856). In: Funes, E.; et al. (eds.). Natureza e Cultura: capítulos de história social. Vol. 10. Expressão Gráfica, Fortaleza. Pp. 146-156.

Matias, L.Q.; Amado, E.R. \& Nunes, E.P. 2003. Macrófitas aquáticas da lagoa de Jijoca de Jericoacoara, Ceará, Brasil. Acta Botanica Brasilica 17: 623-631.

Matias, L.Q. \& Nunes, E.P. 2001. Levantamento florístico da Área de Proteção Ambiental de Jericoacoara, Ceará. Acta Botanica Brasilica 15: 35-43.

Matias, L.Q. \& Sousa, D.J.L. 2011. Alismataceae no estado do Ceará, Brasil. Rodriguésia 62: 887-900.

Matos, R.M.D. 2000. Tectonic evolution of the equatorial South Atlantic. In: Mohriak, W. \& Taiwani, M. (eds.). Atlantic Rifts and Continental Margins. American Geophysical Union, Washington, D. Pp. 331-354.

Matos, R.M.D. 1992. The Northeast Brazilian Rift System. Tectonics 11: 766-791.

McCune, B. \& Grace, J.B. 2002. Analysis of ecological communities. MJM Software Design, Gleneden Beach, Oregon. 300p.

Medeiros, M.B. \& Miranda, H.S. 2008. Post-fire resprouting and mortality in cerrado woody plant species over a three-year period. Edinburgh Journal of Botany 65: 53-68.

Menezes, M.O.T.; Araújo, F.S. \& Romero, R.E. 2010. O sistema de conservação biológica do estado do Ceará: diagnóstico e recomendações. Rede: Revista Eletrônica do Prodema 5: 7-31.

Menezes, M.O.T.; Taylor, N.P. \& Loiola, M.I.B. 2013. Flora do Ceará, Brasil: Cactaceae. Rodriguésia 64: 757-774.

Moreira, M.M.M.A. \& Gatto, L.C.S. 1981. Geomorfologia. In: Brasil, DNPM, Projeto RADAMBRASIL, Folha SA - 24 - Fortaleza. Vol. 21. Rio de Janeiro. Pp. 23-112.

Moro, M.F.; Araújo, F.S.; Rodal, M.J.N. \& Martins, F.R. 2015. Síntese dos estudos florísticos e fitossociológicos realizados no semiárido brasileiro (no prelo). In: Eisenlohr, P.V. et al. (eds.). Fitossociologia no Brasil: métodos e estudos de caso. Vol. II. Editora da Universidade Federal de Viçosa, Viçosa.

Moro, M.F.; Nic Lughadha, E.; Filer, D.L.; Araújo, F.S. \& Martins, F.R. 2014a. A catalogue of the vascular plants of the Caatinga Phytogeographical Domain: a synthesis of floristic and phytosociological surveys. Phytotaxa, 160:1-118.

Moro, M.F.; Sousa, D.J.L. \& Matias, L.Q. 2014 b. Rarefaction, richness estimation and extrapolation methods in the evaluation of unseen plant diversity in aquatic ecosystems. Aquatic Botany 117: 48-55.

Moro, M.F. 2013. Síntese florística e biogeográfica do Domínio Fitogeográfico da Caatinga. Tese de Doutorado em Biologia Vegetal. Universidade Estadual de Campinas, Campinas. 366p.

Moro, M.F.; Castro, A.S.F. \& Araújo, F.S. 2011. Composição florística e estrutura de um fragmento de vegetação savânica sobre os tabuleiros prélitorâneos na zona urbana de Fortaleza, Ceará. Rodriguésia 62: 407-423.

Moura-Fé, M.M. 2008. Evolução Geomorfológica do Sítio Natural de Fortaleza, Ceará. Dissertação de Mestrado em Geografia. Universidade Federal do Ceará, Fortaleza. 248p.

Myers, N.; Mittermeier, R.A.; Mittermeler, C.G.; Fonseca, G.A.B. \& Kent, J. 2000. Biodiversity hotspots for conservation priorities. Nature 403: 853-858.

Nascimento, F.R. 2006. Impactos socioambientais e economia ecológica na zona costeira de SabiaguabaPorto das Dunas. In: Silva, J.B.; Dantas, E.W.C.; Zanella, M.E. \& Meireles, A.J.A. (eds.). Litoral e sertão: natureza e sociedade no nordeste brasileiro. Expressão Gráfica, Fortaleza. 408p.

Nimer, E. 1977. Clima. In: IBGE [Instituto Brasileiro de Geografia e Estatística] (ed.). Geografia do Brasil, Região Nordeste. IBGE, Rio de Janeiro. Pp. 47-84.

Nimer, E. 1972. Climatologia da Região Nordeste do Brasil: Introdução à climatologia dinâmica. Revista Brasileira de Geografia 34: 3-51.

Nimer, E. 1989. Climatologia do Brasil. IBGE, Rio de Janeiro. 421p.

Oliveira, A.C.P.; Penha, A.S.; Souza, R.F. \& Loiola, M.I.B. 2012. Composição florística de uma comunidade savânica no Rio Grande do Norte, Nordeste do Brasil Material e métodos. Acta Botanica Brasilica 26: 559-569.

Oliveira, T.S. \& Araújo, F.S. 2007. Diversidade e conservação da biota na Serra de Baturité, Ceará. Editora da Universidade Federal do Ceará COELCE, Fortaleza. 465p.

Oliveira-Filho, A.T. \& Carvalho, D.A. 1993. Florística e fisionomia da vegetação no extremo norte do litoral da Paraíba. Revista Brasileira de Botânica 16: $115-130$.

Paiva, M.P. 2002. Os naturalistas e o Ceará. Instituto do Ceará, Fortaleza. 354p.

Pereira, M.R.M. \& Santos, R.M.F. 2012. João da Silva Feijó: um homem de ciência no antigo regime português. Editora da Universidade Federal do Paraná, Curitiba. 1046p. 
Pereira, R.C.M. \& Silva, E.V. 2005. Solos e vegetação do Ceará: características gerais. In: Silva, J.B.; Cavalcante, T.C. \& Dantas, E.W.C. (eds.). Ceará: um novo olhar geográfico. Edições Demócrito Rocha, Fortaleza. 480p.

Peulvast, J.-P. \& Claudino-Sales, V. 2006. Reconstruindo a evolução morfotectônica da margem passiva do Nordeste brasileiro. In: Silva, J.B.; Lima, L.C. \& Elias, D. (eds.). Panorama da Geografia Brasileira. Anna Blume, São Paulo. Pp. 47-99.

Peulvast, J.-P. \& Claudino-Sales, V. 2004. Stepped surfaces and palaeolandforms in the northern Brazilian "Nordeste": constraints on models of morphotectonic evolution. Geomorphology 62: 89-122.

Pinheiro, E.D.S. \& Durigan, G. 2009. Dinâmica espaçotemporal (1962-2006) das fitofisionomias em unidade de conservação do Cerrado no sudeste do Brasil. Revista Brasileira de Botânica 32: 441-454.

Porembski, S. 2007. Tropical inselbergs: habitat types, adaptive strategies and diversity patterns. Revista Brasileira de Botânica 30: 579-586.

Queiroz, L.P. 2009. Leguminosas da Caatinga. Editora da Universidade Estadual de Feira de Santana, Feira de Santana. 443p.

Queiroz, L.P. 2006. The Brazilian caatinga: phytogeographical patterns inferred from distribution data of the Leguminosae. In: Pennington, R.T.; Lewis, G.P. \& Ratter, J.A. (eds.). Neotropical savannas and dry forests: Plant diversity, biogeography, and conservation. Taylor \& Francis; CRC Press, Boca Raton. Pp. 121-157.

Ratter, J.A., Bridgewater, S. \& Ribeiro, J.F. 2003. Analysis of the floristic composition of the Brazilian cerrado vegetation III: comparison of the woody vegetation of 376 areas. Edinburgh Journal of Botany 60: 57-109.

Ribeiro, J.F. \& Walter, B.M.T. 2008. As principais fitofisionomias do bioma cerrado. In: Sano, S.M.; Almeida, S.P. \& Ribeiro, J.F. (eds.). Cerrado: ecologia e flora. Embrapa, Brasília. Pp. 151-212.

Ribeiro-Silva, S.; Medeiros, M.D.; Gomes, B.M.; Seixas, E.N.C. \& Silva, M.A.P. 2012. Angiosperms from the Araripe National Forest, Ceará, Brazil. Check List 8: 744-751.
Silva, J.B. \& Cavalcante, T.C. 2004. Atlas escolar, Ceará: espaço geo-histórico e cultural. Editora Grafset, João Pessoa. 200p.

Simon, M.F.; Grether, R.; Queiroz, L.P.; Skema, C.; Pennington, R.T. \& Hughes, C.E. 2009. Recent assembly of the Cerrado, a neotropical plant diversity hotspot, by in situ evolution of adaptations to fire. Proceedings of the National Academy of Sciences of the United States of America 106: 20359-20364.

Soares Neto, R.L.; Magalhães, F.Á.L.; Tabosa, F.R.S.; Moro, M.F.; Costa e Silva, M.B. \& Loiola, M.I.B. 2014. Flora do Ceará, Brasil: Capparaceae. Rodriguésia 65: 671-684.

Sousa, D.J.L. \& Matias, L.Q. 2013. A família Nymphaeaceae no estado do Ceará, Brasil. Rodriguésia 64: 49-59.

Souza, M.J.N. 1988. Contribuição ao estudo das unidades morfo-estruturais do estado do Ceará. Revista de Geologia 1: 73-91.

SUDEC [Superintendência do Desenvolvimento do Estado do Ceará]. 1986. Atlas do Ceará. SUDEC, Fortaleza. 57p.

SUDENE [Superintendência de Desenvolvimento do Nordeste]. 1999. Cartas Topográficas. Escala 1:100.000.

Tabosa, A.B.; Matias, L.Q. \& Martins, F.R. 2012. Live fast and die young: The aquatic macrophyte dynamics in a temporary pool in the Brazilian semiarid region. Aquatic Botany 102: 71-78.

Vasconcelos, S.F.; Araújo, F.S. \& Lopes, A.V. 2010. Phenology and dispersal modes of wood species in the Carrasco, a tropical deciduous shrubland in the Brazilian semiarid. Biodiversity and Conservation 19: 2263-2289.

Veloso, H.P.; Rangel-Filho, A.L.R. \& Lima, J.C.A. 1991. Classificação da vegetação brasileira, adaptada a um sistema universal. Instituto Brasileiro de Geografia e Estatística, Rio de Janeiro. 124p.

Zanella, M.E. 2005. As características climáticas e os recursos hídricos do Estado do Ceará. In: Silva, J.B.; Cavalcante, T.C.; Dantas, E.W.C. (eds.). Ceará: um novo olhar geográfico. Edições Demócrito Rocha, Fortaleza. 480p. 
